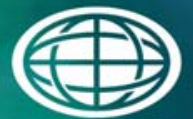

Savannah River

National Laboratory ${ }^{\mathrm{m}}$

OPERATED BY SAVANNAH RIVER NUCLEAR SOLUTIONS

\title{
Glass Fabrication and Analysis Literature Review and Method Selection for WIP Waste Feed Qualification
}

D.K. Peeler

June 2013

SRNL-STI-2013-00187 
SRNL-STI-2013-00187

Revision 0

\section{DISCLAIMER}

This work was prepared under an agreement with and funded by the U.S. Government. Neither the U.S. Government or its employees, nor any of its contractors, subcontractors or their employees, makes any express or implied:

1. warranty or assumes any legal liability for the accuracy, completeness, or for the use or results of such use of any information, product, or process disclosed; or

2. representation that such use or results of such use would not infringe privately owned rights; or

3. endorsement or recommendation of any specifically identified commercial product, process, or service.

Any views and opinions of authors expressed in this work do not necessarily state or reflect those of the United States Government, or its contractors, or subcontractors.

\section{Printed in the United States of America \\ Prepared for U.S. Department of Energy}




\section{Glass Fabrication and Analysis Literature Review and Method Selection for WTP Waste Feed Qualification}

D.K. Peeler

June 2013

Prepared for the U.S. Department of Energy under contract number DE-AC09-08SR22470. 


\section{REVIEWS AND APPROVALS}

AUTHORS:

D.K. Peeler, Process Technology Programs

Date

TECHNICAL REVIEW:

K.M. Fox, Engineering Process Development

Date

APPROVAL:

D.J. Adamson, SRNL WTP Waste Qualification Program Lead

Date

C.C. Herman, Manager

Date

SRNL Hanford Program Manager

S. L. Marra, Manager

Date

Environmental \& Chemical Process Technology Research Programs 


\section{EXECUTIVE SUMMARY}

The waste feed qualification program is being developed to protect the Hanford Tank Waste Treatment and Immobilization Plant (WTP) safety basis, technical basis, and design by assuring waste acceptance requirements are met for each staged waste feed Campaign prior to transfer from the Hanford Tank Farm to the WTP. The three components of waste feed qualification include:

- Demonstrate compliance with the waste acceptance criteria

- Determine waste processability

- Demonstrate unit operations at laboratory scale

This literature review addresses the final step of unit operations testing of radioactive Tank Farm samples - the glass fabrication unit operation. Based on Savannah River National Laboratory's review, the following apparatus are needed by the waste feed qualification laboratory:

- A high speed, low shear remotable mixer such as the LabRAM or similar to mix the feed and ensure homogenous and representative samples can be obtained to support compositional and rheology measurements.

- A remotable Haake M5/RV30 rotoviscometer or similar to perform rheological measurements of the melter feed streams.

- A resistance heated remotable laboratory furnace such as a CM Bottom loaded, elevator furnace (Model $1708 \mathrm{BL}$ ) or similar to fabricate the glass coupons.

- Platinum or platinum-alloy crucibles (100 or $250 \mathrm{~mL}$ with reinforced rims) to fabricate the glass coupons.

The following measurements are recommended:

- Compositional analysis of waste sample to identify types and quantities of glass former materials

- Hydrogen generation rate of waste sample before or after addition of glass former materials

- Rheology of waste sample prior to addition of glass former materials

- Rheology of waste sample after addition of glass former materials

- Compositional analysis of waste sample after addition of glass former materials

- Visual observation of glass coupon

It should be noted that use of cooling curves to evaluate nepheline formation (or any other forms of crystallization) is not required during the glass fabrication unit operation. The glass formulation algorithms to be used during waste feed qualification and waste processing in the LAW and HLW facilities are developed to ensure that the canister cooled glass meets the Waste Acceptance Product Specifications during actual production, and include a discriminator that restricts the production of glasses that are prone to nepheline formation. 


\section{TABLE OF CONTENTS}

LIST OF FIGURES vii

LIST OF ABBREVIATIONS viii

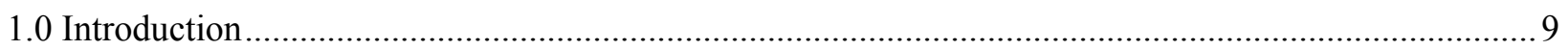

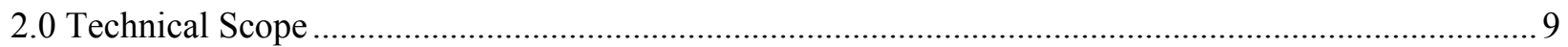

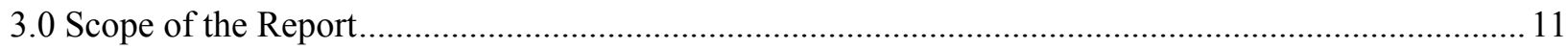

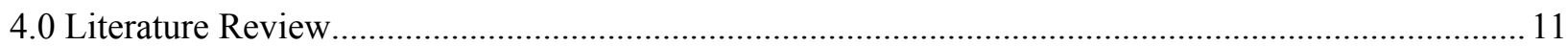

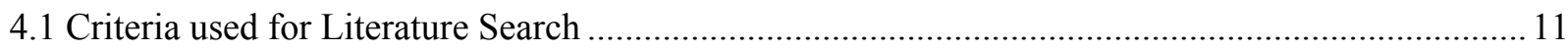

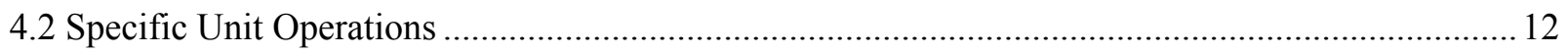

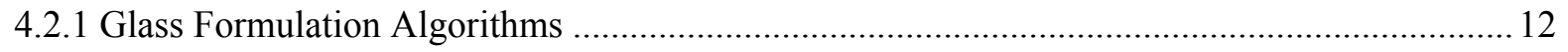

4.2.2 Mixing, Sampling and Rheology Measurements................................................................. 13

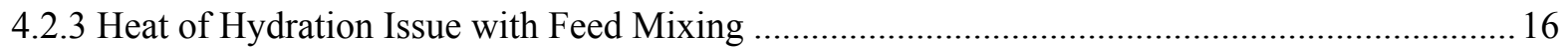

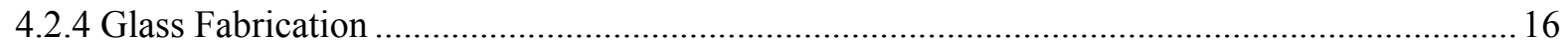

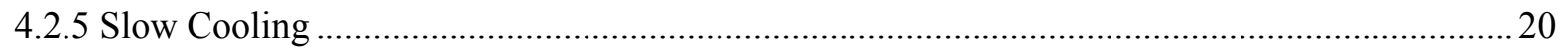

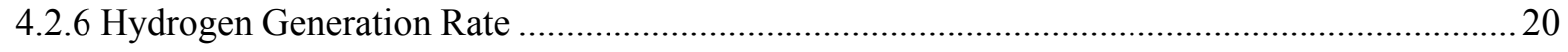

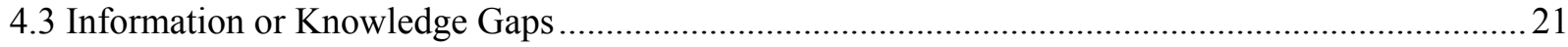

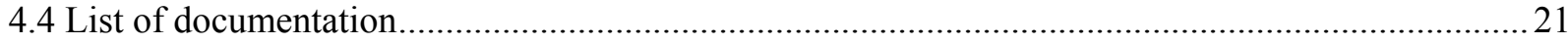

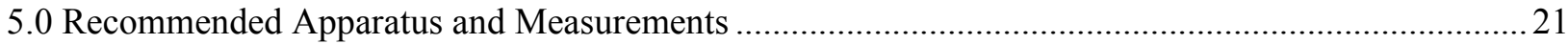

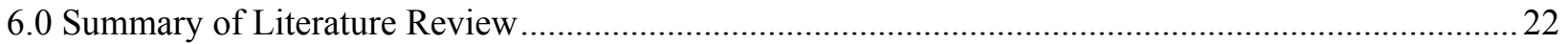

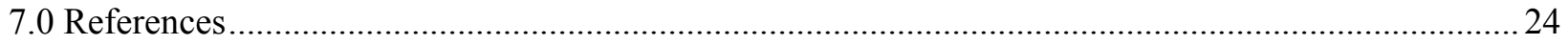




\section{LIST OF FIGURES}

Figure 2-1. Schematic of HLW and LAW Glass Fabrication Unit Operation under the Waste Feed

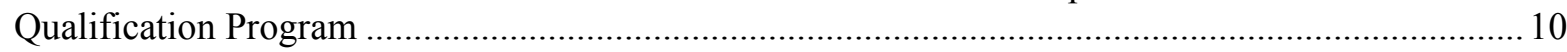

Figure 4-1. Example of LabRAM System That Could Be Used to Support Rheological Measurements

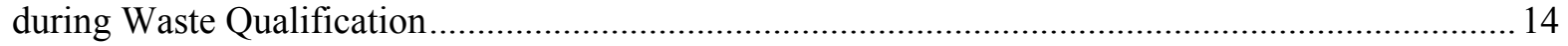

Figure 4-2. Example of Viscoline System That Could Be Used to Support Rheological Measurements during Waste Qualification.................................................................................................. 15

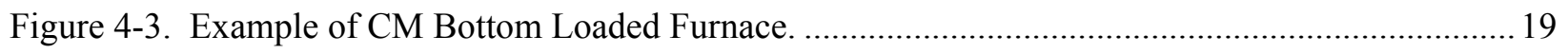

Figure 4-4. Example of Pt Crucibles Used to Convert Melter Feed into a Glass Product........................ 19 


\section{LIST OF ABBREVIATIONS}

$\begin{array}{ll}\text { AES } & \text { atomic emission spectroscopy } \\ \text { CNP } & \text { cesium nitric acid recovery process system } \\ \text { CUF } & \text { cell unit filter } \\ \text { DWPF } & \text { Defense Waste Processing Facility } \\ \text { EA } & \text { environmental assessment } \\ \text { HGR } & \text { hydrogen generation rate } \\ \text { HLW } & \text { high-level waste } \\ \text { HLP } & \text { HLW lag storage and feed blending process system } \\ \text { HMP } & \text { HLW melter process system } \\ \text { ICP } & \text { inductively coupled plasma } \\ \text { IEWO } & \text { inter-entity work order } \\ \text { IHLW } & \text { immobilized high-level waste } \\ \text { ILAW } & \text { immobilized low-activity waste } \\ \text { ISAP } & \text { integrated sampling and analysis plan } \\ \text { LAW } & \text { low-activity waste } \\ \text { LMP } & \text { LAW melter process system } \\ \text { MFV } & \text { melter feed vessel } \\ \text { MS } & \text { mass spectrometry } \\ \text { PJM } & \text { pulse jet mixer } \\ \text { SRNL } & \text { Savannah River National Laboratory } \\ \text { SRS } & \text { Savannah River Site } \\ \text { TRU } & \text { transuranic } \\ \text { UFP } & \text { ultrafiltration process } \\ \text { WTP } & \text { Hanford Tank Waste Treatment and Immobilization Plant }\end{array}$




\subsection{Introduction}

The waste feed qualification program is being developed to protect the Hanford Tank Waste Treatment and Immobilization Plant (WTP) safety basis, technical basis, and design by assuring waste acceptance requirements are met for each staged waste feed Campaign prior to transfer from the Hanford Tank Farm to the WTP. The three components of waste feed qualification include (Benson and Halverson 2013):

- Demonstrate compliance with the waste acceptance criteria

- Determine waste processability

- Demonstrate unit operations at laboratory scale

This document addresses the glass fabrication unit operations test apparatus and is one of a series of literature reviews and methodology recommendations addressing development of the waste feed qualification program capability. The glass fabrication unit operation consists of combining waste feed streams with glass forming materials, performing rheological measurements, and fabricating glass coupons for analysis.

This work documents scaling, design, and operation of the glass fabrication test apparatus, and experimental setup, including configuration, data collection, and remote handling of the glass fabrication unit operations test apparatus. Further, this document identifies:

- Criteria used for the literature search

- List of documents

- Applicability of each document to the development and use of the glass fabrication unit operations test apparatus

- Information gaps and closure recommendations

This document is prepared to support completion of Waste Qualification Program Development Task 1 of SCT-M0SRV00028-00-012, "Inter-Entity Work Order M0SRV00028 Task 12".

\subsection{Technical Scope}

The activities associated with the glass fabrication unit operation are described in the Waste Feed Qualification Program Plan (Benson and Halverson 2013) and include a number of steps. The types and quantities of glass forming materials to be mixed with the low-activity waste (LAW) and high-level waste (HLW) feeds are determined using the appropriate glass formulation algorithm, and the results of analysis of the treated LAW (ion exchange effluent) and concentrated HLW (cell unit filter (CUF) slurry and acid regeneration eluate from the laboratoryscale ion exchange column). Specifics regarding the glass formulation algorithms are found within 24590-HLW-RPT-RT-05-001, Preliminary IHLW Formulation Algorithm Description (Vienna and Kim 2008), as well as within 24590-LAW-RPT-RT-04-0003, Preliminary ILAW Formulation Algorithm Description (Kim and Vienna 2012). Once the glass formers are added, rheological measurements are made and the mixtures are then vitrified at the crucible scale using the nominal melt temperatures identified in 24590-LAW-3YD-LMP-00001, System Description for the System LMP, Low Activity Waste Melter (Parker 2010), and in 24590-HLW-3YD-HMP00001, System Description for the HLW Melter Process System (HMP) (Kufahl 2010). Composition and / or physical analysis are performed on the resulting product.

This process is depicted in Figure 2-1 (from CCN: 248476, Benson 2013). 


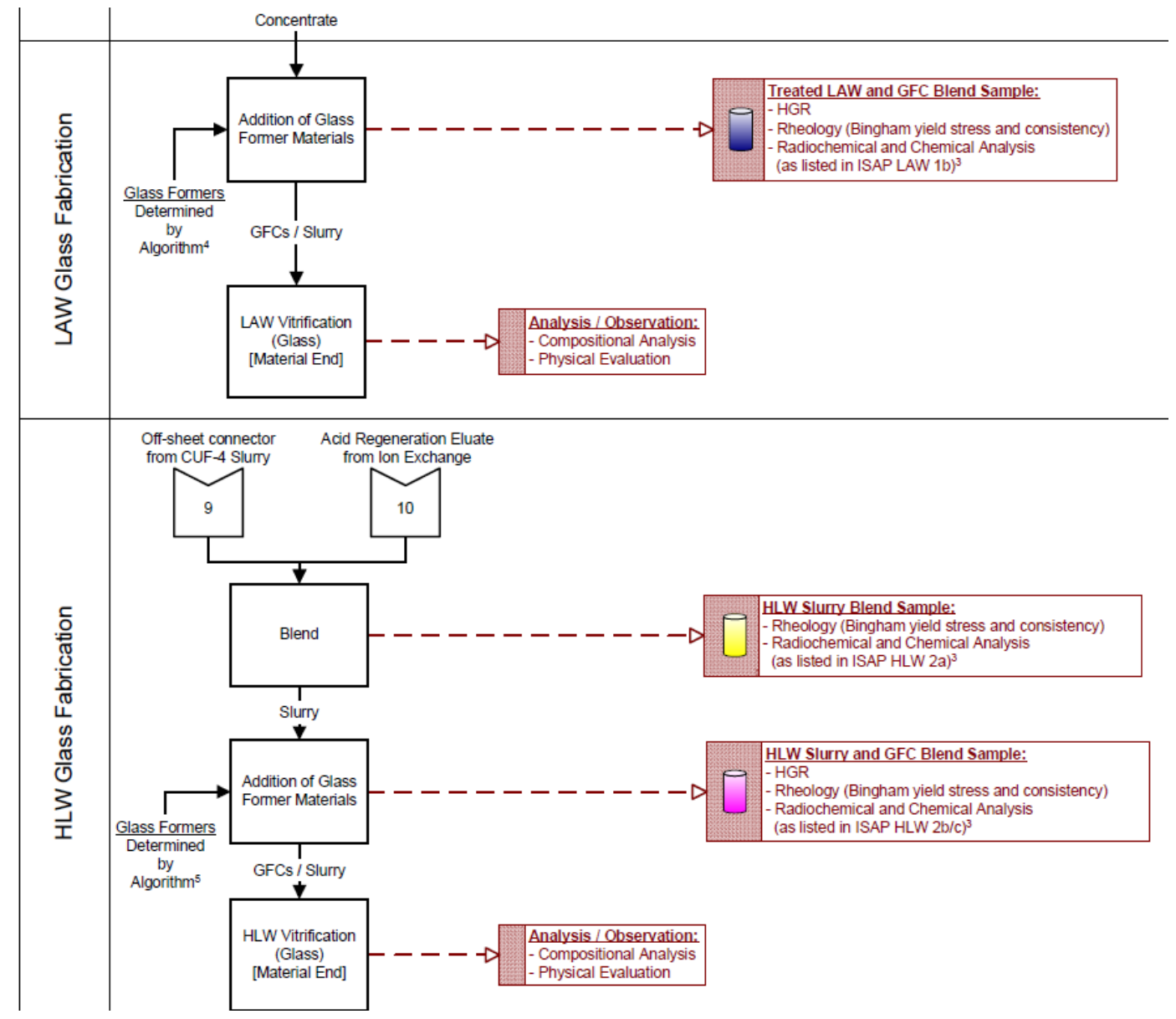

Figure 2-1. Schematic of HLW and LAW Glass Fabrication Unit Operation under the Waste Feed Qualification Program (Benson 2013) ${ }^{1}$.

\footnotetext{
${ }^{1}$ The acronym ISAP is Integrated Sampling and Analysis Plan (ISAP), 24590-LAB-PL-OP-12-0001 by Arakali and Johnston (2013). LAW 1b, HLW 2a, HLW 2b/c are analytical reports identified in the ISAP that are generated from analyses of samples taken at specific points within the LAW and HLW Facilities.
} 
Selection of glass forming material types and quantities used during waste qualification are to support rheological measurements and preparation of HLW and LAW glasses. Glass forming material types and quantities selected for use during actual waste processing are determined through evaluation of melter feed preparation vessel sample results and the use of the appropriate glass formulation algorithm. Waste feed qualification testing and resulting data are not immobilized high-level waste (IHLW) acceptance impacting (24590-HLW-RWF-ENG-12-0001, Waste Acceptance Impacting Initial Review Form for Waste Feed Qualification Program).

\subsection{Scope of the Report}

The objective of this literature review is to identify and review documents to address scaling, design, operations, and experimental setup, including configuration, data collection, and remote handling that would be used during waste feed qualification in support of the glass fabrication unit operation. Items addressed include:

- LAW and HLW glass formulation algorithms

- Mixing and sampling

- Rheological measurements

- Heat of hydration

- Glass fabrication techniques

- Glass inspection

- Composition analysis

- Use of cooling curves

- Hydrogen generation rate measurement

\subsection{Literature Review}

The following were assessed for the glass fabrication unit operation:

- Criteria used for the literature search

- Specific unit operations for the following items:

o LAW and HLW glass formulation algorithms

o Mixing and sampling

o Rheological measurements

o Heat of hydration

o Glass fabrication techniques

o Glass inspection

o Composition analysis

o Use of cooling curves

o Hydrogen generation rate measurement

- Information or knowledge gaps

- List of documentation and the applicability of each document to the development and use of the glass fabrication unit operations test apparatus

\subsection{Criteria used for Literature Search}

The literature reviewed as part of this scope focused on three primary technical areas: (1) the LAW and HLW glass algorithms as they pertain or apply to compositional regions anticipated to 
be processed through the WTP; (2) technical needs, requirements, and equipment to support mixing and sampling of both LAW and HLW wastes and melter feeds; and (3) the approaches and equipment required to support glass fabrication and subsequent characterization or analysis. The primary criterion for inclusion of documents in the review was based on applicability or relevancy of the literature to the intended scope as well as the need to provide a technical basis for the recommendations being made to WTP to glass fabrication unit operations to be performed during this portion of the waste feed qualification program. It should be noted that there is a large body of technical work that has been performed to support glass formulation efforts to WTP that was not included in this review given the literature did not apply to the glass fabrication unit operation. Therefore, the primary literature review focused on test methods, approaches or procedures, equipment needs, and analytical protocols needed to support the waste feed qualification efforts under the glass fabrication unit operation. A primary source of the review is based on the multiple years (18+ years) of SRNL experience in supporting qualification efforts for the Defense Waste Processing Facility (DWPF) at the Savannah River Site (SRS) with consideration for the differences between the two qualification approaches.

\section{2 $\underline{\text { Specific Unit Operations }}$}

\subsubsection{Glass Formulation Algorithms}

In order for the melter feed and glass coupon to be prepared for analyses, glass formulation algorithms are necessary to determine the proper proportion and type of glass forming materials. LAW and HLW glass formulation algorithms have been documented (Preliminary IHLW Formulation Algorithm Description, 24590-HLW-RPT-RT-05-001 (Vienna and Kim 2008) and Preliminary ILAW Formulation Algorithm Description, 24590-LAW-RPT-RT-04-0003 (Kim and Vienna 2012) and determined acceptable for production of IHLW and immobilized low-activity waste (ILAW) in the WTP product qualification reports (Nelson et. al 2007 and Nelson 2010). These glass formulation algorithms are used to determine the appropriate blend of glass forming materials to be added to each batch of feed entering the vitrification facility (HLW or LAW) to ensure all vitrification processing and disposal constraints are met (Benson et. al 2012; Markillie Meinert (2011)). These algorithms have been developed, tested, and vetted over a contractually compliant limited set of Hanford tank waste compositions, but are expected to be developed over the life of the Hanford waste disposition program to cover the necessary ranges of waste to be processed. For the purposes of the waste feed qualification program, these algorithms will be approved for use for the particular batch campaign being tested in the waste feed qualification program.

Glass formulation studies and subsequent development of the HLW glass formulation algorithm were based on waste characterization results from Hanford tanks AZ-101, AZ-102, C-104, AY102/C-106 (see Section 2.1.2.8 of Kim 2010). The compositional gaps between the algorithm and the anticipated HLW compositional range to be processed through the WTP are currently being addressed through an integrated testing program (see Vienna et al. 2013 as an example).

Glass formulation studies and subsequent development of the LAW glass formulation algorithm were based on waste characterization results from Hanford tanks AN-105, AP-101, AN-104, AZ101, AZ-102, AN-107, and AN-102 (see Section 4.2.2.1 of Kim and Vienna (2012)). The compositional gaps between the algorithm and the anticipated LAW compositional range to be processed through the WTP are currently being addressed through an integrated testing program (see Muller et al. 2013 and Vienna et al. 2013 as examples). 


\subsubsection{Mixing, Sampling and Rheology Measurements}

Mixing and sampling will be important to the successful operation of the WTP and the waste feed qualification process with respect to transferring materials from one vessel to another and sampling to ensure representative samples are obtained for the measurements required. The extent of mixing required will depend on specific unit operations since physical properties and waste type can change throughout the facilities. Waste feed qualification program testing will be performed to verify that the inputs to and products of the unit operations will be within predefined bounds for the mixing equipment and transfer lines. With respect to sampling, some streams will be more challenging for obtaining a representative sample and protocols will need to be implemented (that may vary across the different unit operations) to ensure that campaign decisions are made with necessary and accurate data. A potential issue with Hanford related samples is the rate of settling and its impact on sampling. If fast settling solids are present, issues could arise with obtaining representative samples during waste feed qualification.

Rheological measurements are performed as part of the waste feed qualification program. Of particular interest will be the impacts of particle size changes that may occur before (or during the measurement), soluble species and their impact on the measurement, and shear rate. Smith and Prindiville (2002) provide guidelines on performing rheological measurements for WTP. Koopman (2004) provides the protocols used for measuring slurry samples for DWPF which would also be applicable to WTP.

To support the waste feed qualification process, a system will be developed that can serve as the mixing and sampling unit for waste and melter feeds for both LAW and HLW flowsheets. Mixing waste or melter feed could be accomplished by a high speed, low-shear laboratory mixer such as the LabRAM (see Figure 4-1). The LabRAM (by Resodyn Acoustic Mixers) a unit claims to thoroughly mix liquids, solids, powders and very viscous compounds with a nominal capacity of approximately 0.5 liter. A variety of mixing vessels may be used including small vials and disposable plastic containers and bags. This operational flexibility would allow different nominal capacity vials/bottle to be utilized depending on the ultimate volume of material needed to support downstream activities (i.e., rheology measurements, glass fabrication, and analysis). Mixing versatility, quick sample turnaround, and the ability to adequately and safely mix hazardous materials are specific characteristics of a mixer needed to support the waste feed qualification efforts. SRNL routinely uses this mixer to support simulant work to support DWPF qualification efforts. Samples from the LabRAM could then be transferred to a rheometer for formal rheology measurements. It should be mentioned that the LabRAM is only being used as an example of a high speed, low-shear mixer that could be used to support mixing and sampling needs. In fact, if the LabRAM is further considered during the conceptual design stage of the project, an assessment will have to be made as to the viability to isolate the electronics package of this system for remotability in a cells environment. Other mixers (perhaps simpler) could also be utilized to support this portion of the waste qualification program.

In order to perform rheology measurements, a rotoviscometer is recommended. The Haake $\mathrm{M}$ /RV30 rotoviscometer is normally used for measuring SRS tank sludge and a MV1 rotor is typically used. For the DWPF melter feed, the MV II rotor is used to perform the measurements, due to the larger frit particles that are present in the melter feed. The MV II has a larger gap to accommodate the larger frit particles. Regardless of the type of equipment to be utilized during the waste feed qualification program, an assessment (a paper study or an experimental program

\footnotetext{
${ }^{\mathrm{a}}$ Footprint of the LabRAM is 16 inches $(41 \mathrm{~cm})$ diameter, 25 inches $(61 \mathrm{~cm})$ high and is benchtop mountable.
} 
through the use of simulants) of the appropriate rotor would be required to ensure glass former additions would not have an impact on the rheology measurement.

The flow curves for the sludge created from the output of the rotoviscometer are fitted to the down curves using the Bingham Plastic rheological model, Equation 1, where $\tau$ is the measured stress (Pascal), $\tau_{\mathrm{o}}$ is the Bingham Plastic yield stress (Pascal), $\mu_{\infty}$ is the plastic viscosity (Pascal-second), and $\dot{\gamma}$ is the measured shear rate $\left(\right.$ second $\left.^{-1}\right)$. During all these measurements, the sample remains in the cup for the second measurement, due to the limited sample availability.

Equation 1

$$
\tau=\tau_{o}+\mu_{\infty} \dot{\gamma}
$$

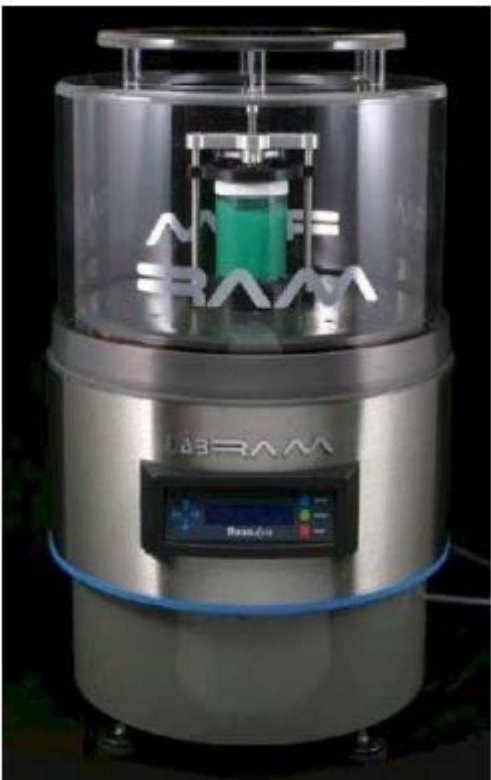

\section{Figure 4-1. Example of LabRAM System That Could Be Used to Support Rheological Measurements during Waste Qualification}

Another option available to support rheological measurements is the VISCOLINE in-line process rheometer by Krohne, Incorporated. Literature on the VISCOLINE rheometer indicates it provides in-line, continuous measurement of fluid viscosity for process control and monitoring applications (see Figure 4-2). Operationally, fluid flows through a continuous pipe containing two low pressure drop static mixers. A sensor device measures the pressure drop at both static mixers by means of two differential pressure measurements: $\Delta \mathrm{P} 1$ and $\Delta \mathrm{P} 2$. Precise pipe flow rate measurement is obtained from the integrated KROHNE OPTIMASS 7000 straight tube Coriolis meter which is uniquely insensitive to fluid viscosity effects. Pipe flow rate obtained from KROHNE's OPTIMASS straight tube meter is integrated in the Viscoline. From the two pressure drop measurements and the flow rate reading, the fluid flow parameters are processed in the system, and the pipe line viscosity is determined. A temperature reading can be useful for thermal correction when a reference measurement is required. Such correction requires laboratory thermal characterization or dual measurement. 
Although the VISCOLINE rheometer provides continuous in-line monitoring, discussions with the vendor suggested that sample volumes to provide continuous flow would range upward of $>0.6$ gallon per minute (for the smallest 0.5 in tubing in the current design) and the equipment footprint would be approximately five feet long by 3 feet high. Even if the footprint were acceptable, the sample volume $(>0.6$ gallon $/ \mathrm{min})$ may off-set or negate any perceived advantages the VISCOLINE may have over the use of the LabRAM coupled with the rheometer such as the Haake (as discussed above). In addition, remotability of the VISCOLINE does not appear to be straight forward. The vendor indicated that the VISCOLINE was a new product line which was currently not designed for remote operations and additional research and development as well as design would be required to reduce the footprint and sample volume size. SRNL does not recommend the use of the VISCOLINE instrument based on its experience with equipment in a radioactive shielded cells environment and its history of using the Haake rotoviscometer. The potential complications of using the VISCOLINE instrument include its unproven design in a radioactive environment, sample volume needs, significant challenges expected with cleaning the system, unknown reliability of the equipment/parts in a high radiation field, and expansive footprint requirements.

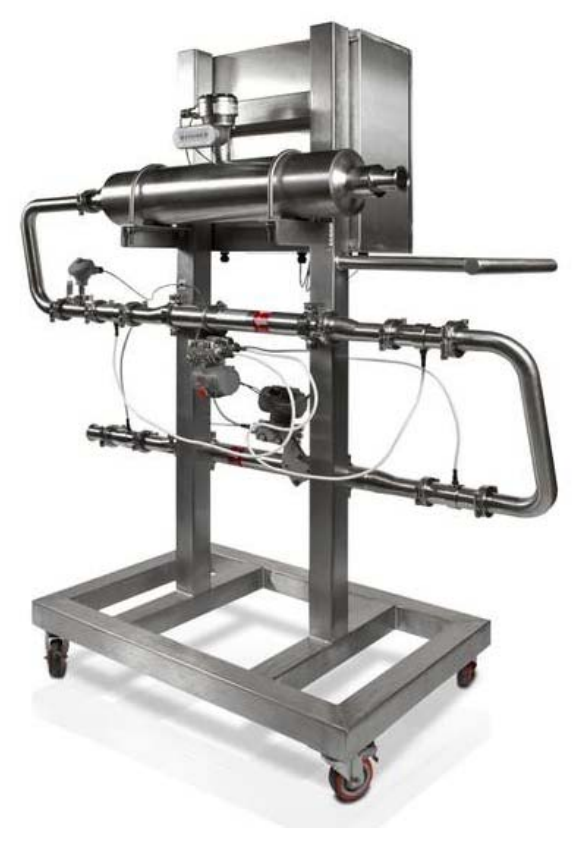

\section{Figure 4-2. Example of Viscoline System That Could Be Used to Support Rheological Measurements during Waste Qualification}

The ability of the mixer to adequately mix the sludge and/or melter feed without distorting the physical properties is critical to obtaining rheology measurements to support facility operations. For example, high shear systems should be avoided because they can reduce the particle size of the sludge or glass formers. If particle size or particle size distributions are modified by the mixer, then rheology measurements can be altered. If this occurs, then the rheology measurements performed during waste feed qualification may be meaningless with respect to the assessment of the ability to mix and transfer materials in the WTP process. Therefore a low shear, high speed mixer will be identified to support waste feed qualification efforts to ensure adequate mixing (for 
subsampling) while minimizing any adverse changes to the material to ensure rheological measurements can be taken and compared to predefined constraints.

Based on this review, it is recommended that WTP consider the use of the low-shear, high speed LabRAM mixer (to ensure adequate mixing and subsequent subsampling for analytical or rheological measurements) coupled with a proven Haake rheometer (for rheological measurements) to support waste feed qualification efforts. This recommendation is based on operational experience (with both the LabRAM and the Haake) to support DWPF qualification and radioactive sample characterization efforts, size or footprint, ease of remotability, and sample size requirements.

\subsubsection{Heat of Hydration Issue with Feed Mixing}

As described by Martinelli et al. (2012), treated solids and the Sr/TRU precipitate from the Ultrafiltration Process (UFP) can be received in the HLW Lag Storage Vessels (HLP-VSL00027A/B) and/or the HLW Feed Blend Vessel (HLP-VSL-00028). Cesium (Cs) concentrate from the cesium nitric acid recovery process system (CNP) may be received in HLP-VSL00027B or HLP-VSL-00028. Caustic (19 molar NaOH) is added to the HLP vessel receiving the Cs concentrate prior to transfer as a buffer and to neutralize the acid in the Cs concentrate. The receipt of the Cs concentrate will be dependent on the available vessel volumes. HLP-VSL00028 receives feed from HLP-VSL-00027A/B and stages the HLW vitrification feed prior to transfer.

The primary sources of heat to HLP-VSL-00028 are decay heat, pulse jet mixers (PJM) mixing operations, the dissolution of 19 molar $\mathrm{NaOH}$, and the neutralization of the CNP Cs concentrate. During waste feed qualification efforts, PJMs will not be utilized so the real concern for heat load comes down to decay heat and the mixing of 19 molar $\mathrm{NaOH}$ and the acidic CNP Cs concentrate stream. To evaluate potential concerns for heat generation during performance of the unit operation, a literature review was performed considering the much smaller volumes being used in the waste feed qualification efforts.

SRNL has previously performed laboratory testing where cesium eluates were combined with pretreated C-106 HLW sludge to produce an IHLW glass waste form (Crawford et al. 2001). Approximately 37 grams of C-106 HLW sludge (which had been caustic leached) was combined with approximately 100 milliliters of concentrated Cs eluate, $\sim 150$ milliliters of radioactive Sr/TRU slurry (at approximately 5 weight percent solids), and a mixture of glass formers to produce approximately 81 grams of HLW glass. Although it is recognized that mixing of the caustic and acidic streams could generate heat, only a small temperature rise was noted $\left(1-2{ }^{\circ} \mathrm{C}\right)$. SRNL will continue to evaluate this potential as the integrated unit operations to support the waste feed qualification efforts are developed. However, based on these results, heat of hydration is not expected to be an issue during waste feed qualification efforts.

\subsubsection{Glass Fabrication}

In the HLW and LAW Vitrification facilities, treated feed is received and the feed concentrate is blended with glass forming materials to ensure it is well mixed. The melter feed slurry is transferred to the melter feed vessels (MFV) and fed to a dedicated HLW or LAW melter(s). The 
HLW and LAW vitrification processes utilize joule-heated ceramic melters and offgas abatement systems.

With respect to HLW and LAW waste feed qualification efforts to support WTP operations, the conversion of the melter feed (representing feed from the MFV) to a glass product will occur in a laboratory setting - not a melter. More specifically, the melter feed will be converted to a glass product through the use of a high temperature furnace at a nominal temperature of $1150^{\circ} \mathrm{C}$. In theory, any type of furnace (resistance or electrically-heated, induction-based, etc.) could be used. However, critical attributes of the furnace must include ease of integration into a cells environment (e.g., power and/or cooling services should be available), ability to attain temperatures up to the anticipated melting temperature of the glass (i.e., nominally $1150^{\circ} \mathrm{C}$ although higher facility melter temperatures have been contemplated $\left(1200^{\circ} \mathrm{C}\right)$ ), natural or forced convection to minimize thermal gradients in the working volume of the furnace, the working volume or capacity to hold a crucible size needed to fabricate the desired amount of glass, and a well-insulated shell to lower heat load or continuous thermal loss into the cells.

To support WTP waste feed qualification efforts, the necessary number of samples (typically analyzed in quadruplicate at SRNL) of the well-mixed melter feed (for both LAW and HLW) should be obtained and placed in an open Pt or Pt-alloy crucible (with reinforced rim). The crucible containing the melter feed should be placed in an oven at $110^{\circ} \mathrm{C}$ until dry. The specifics of the drying process will be elaborated in the procedures for this unit operation. The Pt or Ptalloy crucible with dried melter feed should subsequently be transferred into the furnace (bottom loaded is preferred) at room temperature. The furnace temperature should be slowly increased to $1150^{\circ} \mathrm{C}$ and the sample held at temperature for approximately $1-2$ hours. It should be noted that a heating rate (which could include isothermal holds at various low and intermediate temperatures) should be utilized to avoid potential foam formation due to trapped gases from the decomposition of carbonates, nitrates, nitrites, and other feed or glass formers that are non-oxide based. A slow and controlled temperature increase will minimize foam formation (and the likelihood of material expansion outside of the crucible) without impacting the final composition of the glass product. The specifics of the slow and controlled heating to convert the melter feed into glass will be elaborated in the procedures for this unit operation. Another key parameter which will be evaluated during the conceptual design stage will be the crucible size (or volume) relative to the volume of the melter feed to be converted to a glass product.

After the isothermal hold at $1150^{\circ} \mathrm{C}$ for $1-2$ hours, the Pt or Pt-alloy crucible should be removed from the furnace while at temperature and can either be poured onto a stainless plate or bottom quenched (cooled) in a shallow pan of water, making sure no water contacted the glass during the process. Quenching the crucible in a water batch fractures the glass and allows pieces to be removed relatively easily. Pouring the glass onto a stainless steel plate induces operational risk that may not be warranted to produce the glass product for subsequent analysis or characterization. Based on the Waste Feed Qualification Program Plan (Benson and Halverson 2013), the glass products (HLW and LAW glasses) are to be visually inspected for the "black and shiny" characteristic, and compositionally analyzed. The compositional analysis of the glasses may then be used as input into the glass formulation algorithms to confirm the predicted glass compositions and estimate the process and product performance properties for both the LAW and HLW feed campaigns being qualified.

It should be noted that the sample prepared for compositional analysis could be the same sample used to support visual observations since a glass is typically made to facilitate the analysis of melter feed samples. If so, this has the potential to reduce the overall glass sample mass, which 
would have upstream positive impacts on the sample size needed to support the overall qualification process. The magnitude of that impact could be quantified during the development of the overall integrated flowsheet with respect to sample size requirements. An additional input into the sample size may be the analytical method to be implemented to support compositional analysis as discussed below.

With respect to compositional analysis during waste feed qualification efforts, WTP has several options that could be considered. However, two options appear to be the most technically viable based on previous experience at Hanford and SRNL: (1) use of a laser ablation technique coupled with Inductively Coupled Plasma - Atomic Emission Spectroscopy (ICP-AES) and Mass Spectroscopy (ICP-MS), which is currently the baseline analytical technique for facility operations or (2) use of a digestion/fusion preparation technique followed by ICP-AES and ICPMS analyses. It should be noted that either of these techniques could be utilized by WTP to support the qualification effort. With respect to sample size and glass coupon preparation, the laser ablation technique requires a flat surface while the digestion/fusion preparations do not which may provide some distinction with respect to method selection for waste feed qualification.

Based on SRNL experience supporting DWPF qualification efforts, a CM bottom loaded, elevator furnace (CM Furnaces, Inc, Model 1708 BL or equivalent) is recommended (see Figure 4-3). The system is remotable and the bottom loading feature of the furnace limits heat load into the cells environment. In addition to minimizing heat load into the cells, the bottom loading feature is manipulator friendly by reducing heat exposure as compared to a front loading furnace. The CM Model $1708 \mathrm{BL}$ chamber opening of approximately 8 inches $\times 8.5$ inches with an internal working volume of approximately $8 \times 8 \times 8(\mathrm{WxHxD})$ inches. External dimensions of this bottom loaded model are approximately $13 \times 38 \times 23$ inches $(\mathrm{WxHxD})$. It should be noted that the furnace procured was not "off-the-shelf" but had the gull-wing doors removed, special hardware (e.g., hex-head screws) used to support manipulator friendly access, and special power connections were requested. The vendor still has the design and fabrication specifications for the CM furnaces used in the SRNL shielded cells (if needed). 


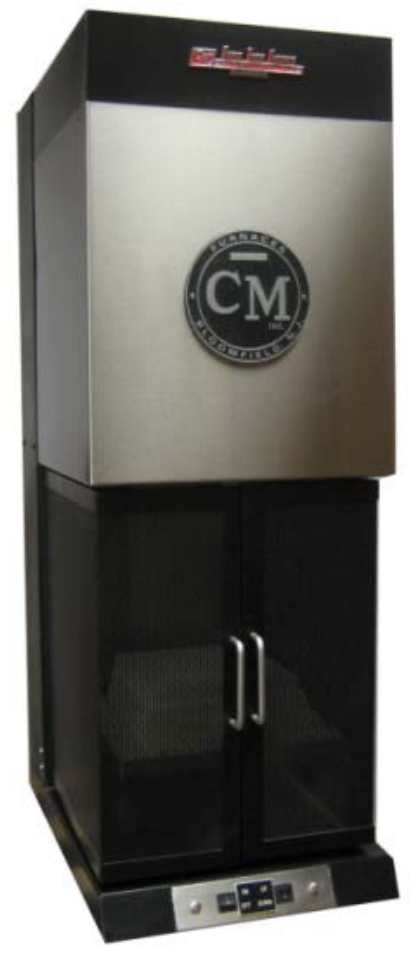

Figure 4-3. Example of CM Bottom Loaded Furnace.

Platinum or Pt-alloy crucibles can be obtained from a variety of manufacturers (e.g., Cole Palmer, Claisse, Kito, Sigma-Aldrich, etc). Figure 4-4 shows an example of a Pt crucible typically used in the SRNL qualification efforts supporting DWPF. The size of the Pt crucible will depend on volume (or mass) of HLW and LAW melter feed being converted to glass and will be bounded by the size of the furnace chamber (or opening). In general, SRNL uses either a $100 \mathrm{~mL}$ or $250 \mathrm{~mL}$ Pt or Pt-alloy crucible in conjunction with the CM bottom loaded, elevator furnace (Model 1708 BL). Pt crucibles can be reused after cleaning with a low temperature flux or acid bath leach to remove any excess glass to avoid cross-contamination of subsequent glasses.

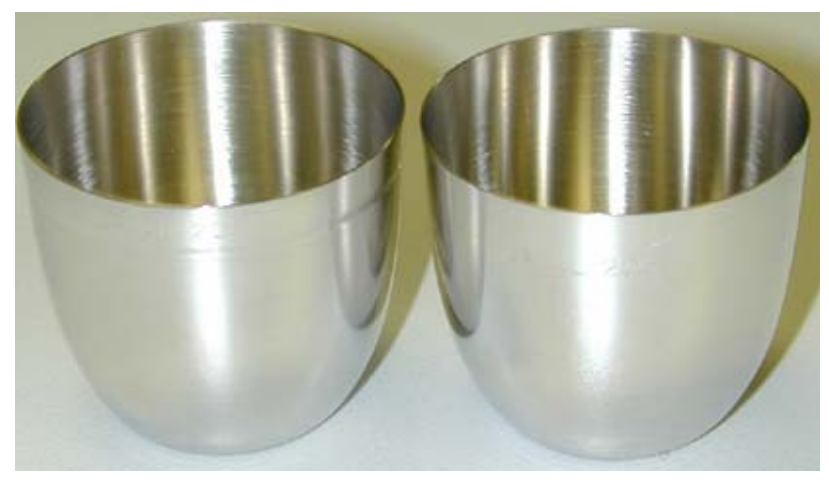

Figure 4-4. Example of Pt Crucibles Used to Convert Melter Feed into a Glass Product. 
These recommendations are based on over 18 years of operational experience at SRNL in support of waste qualification efforts for DWPF. SRNL's qualification efforts in the glass fabrication area are very similar to those being developed by WTP (refer to Pareizs and Crawford (2012) and Pareizs et al. (2011) as a comparison). In general, SRNL analyzes the HLW sludge to determine the type and extent of glass forming materials to be used. The primary difference is the use of a pre-fabricated frit for SRNL as compared to a mixture of glass former materials for WTP. During the SRNL qualification process, the melter feed is converted to a glass product in the CM furnace and the crucible is water quenched. The resulting glass is then compositionally analyzed by ICPAES and ICP-MS. Two different digestion methods (a sodium peroxide fusion at $675^{\circ} \mathrm{C}$ followed by a $\mathrm{HNO}_{3}$ uptake and a mixed acid dissolution in sealed vessels at $115^{\circ} \mathrm{C}$ using a combination of $\mathrm{HF}, \mathrm{HCl}$, and $\mathrm{HNO}_{3}$ acids) are used to ensure all the elements of interest are obtained. Another primary difference between the two qualification efforts is the fact that SRNL experimentally measures the durability response of the glass as part of the waste form compliance protocol, whereas WTP has not included demonstration of acceptability in its waste feed qualification program, because the durability response of the glass is embedded in the WTP glass former algorithm ((Vienna and Kim 2008) and (Kim and Vienna 2012)).

\subsubsection{Slow Cooling}

The Waste Feed Qualification Program Plan (Benson and Halverson 2013) indicates that during waste feed qualification activities, it may be necessary to assess the glass under controlled cooling conditions (cooling curves) in order to simulate the slower cooling rates observed within the interior of the canister (IHLW) or container (ILAW) and ascertain whether the cooling rate kinetically allows for the formation of a crystalline phase (e.g., nepheline crystals).

As an example, it is well known that nepheline formation (Kim et al. 1995, Li et al. 1997, Li et al. 2003, Peeler et al. 2005, Peeler et al. 2006, Fox et al. 2006, Edwards et al. 2006) can have a significant and detrimental impact on the durability of the glass product. In fact, simulated HLW glasses with nepheline crystals embedded due to slow cooling have been shown to exceed the normalized release rates of the benchmark Environmental Assessment (EA) glass (Jantzen et al. 1993). Both the LAW and HLW glass algorithms utilize the nepheline discriminator to avoid formulating glasses that are prone to nepheline formation (Kim and Vienna (2012), and Vienna and Kim (2008)). That is, the nepheline discriminator is embedded in the glass algorithms that ultimately restrict the production of glasses that are prone to nepheline formation.

The glass algorithms will be an integral part of WTP's waste form compliance strategy and these algorithms will be used to define the type and quantity of glass former materials to be added both as part of the waste feed qualification program and in WTP production. The targeted glass composition will have to simultaneously satisfy all of the glass processing and product constraints, including the nepheline discriminator; thus, the potential negative impacts of forming crystals upon cooling should be mitigated. Demonstration of cooling during the waste feed qualification efforts would, therefore, not be considered necessary for either the HLW or LAW samples.

\subsubsection{Hydrogen Generation Rate}

The continuous flow system with online gas analysis method recommended by Stone (Stone 2012) will be used to perform the hydrogen generation rate measurements. 


\subsection{Information or Knowledge Gaps}

Based on the results of the literature survey, there were no information or knowledge gaps identified relative to the scope objectives.

\subsection{List of documentation}

Appendix A and Appendix B provide a list of documents that were reviewed as part of this literature survey. Those documents listed in Appendix A were directly applicable to support the scope objectives. A general comment is provided for these documents to capture the basis for their use in the literature review. In addition, the subject matter or scope (i.e., LAW and HLW glass formulation algorithms, mixing and sampling, rheological measurements, heat of hydration, use of cooling curves, and/or hydrogen generation rate measurement) to which the reference was relevant is denoted. Those documents listed in Appendix B were reviewed but were excluded from the literature review.

\subsection{Recommended Apparatus and Measurements}

Based on the above literature, the following apparatus and measurements are recommended for the waste feed qualification laboratory to perform the glass fabrication unit operations testing:

\section{Creation and Mixing of Slurry Samples}

- A high speed, low shear remotable mixer such as the LabRAM or similar should be used to mix the feed and ensure homogenous and representative samples can be obtained to support compositional and rheology measurements.

\section{Rheology Measurement}

- A remotable Haake M5/RV30 rotoviscometer or similar should be used to perform rheological measurements of the melter feed streams.

\section{Glass Fabrication}

- A laboratory furnace such as a CM Bottom loaded, elevator furnace (Model $1708 \mathrm{BL}$ ) or similar should be used to fabricate the glass coupons.

- Platinum or platinum-alloy crucibles (100 or $250 \mathrm{~mL}$ with reinforced rims) should be used in fabricating the glass coupons.

The following measurements are recommended:

- Compositional analysis of waste sample to identify types and quantities of glass former materials

- Hydrogen generation rate of waste sample before or after addition of glass former materials (refer to Stone (2013) for more details on this measurement)

- Rheology of waste sample prior to addition of glass former materials

- Rheology of waste sample after addition of glass former materials

- Compositional analysis of waste sample after addition of glass former materials

- Visual observation of glass coupon 


\subsection{Summary of Literature Review}

The waste feed qualification program is being developed to protect the WTP safety basis, technical basis, and design by assuring waste feed acceptance requirements are met for each staged waste feed Campaign prior to transfer from the Tank Farm to the WTP. The three components of waste feed qualification include:

- Demonstrate compliance with the waste acceptance criteria

- Determine waste processability

- Demonstrate unit operations at laboratory scale

This literature review addresses the final step of unit operations testing - the glass fabrication unit operation. The objective of this literature review was to identify and review documents to address scaling, design, operations, and experimental setup, including configuration, data collection, and remote handling that would be used during waste feed qualification in support of the glass fabrication unit operation. Specific items addressed include:

- LAW and HLW glass formulation algorithms

- Mixing and sampling

- Rheological measurements

- Heat of hydration

- Glass fabrication techniques

- Glass inspection

- Composition analysis

- Use of cooling curves

- Hydrogen generation rate measurement

For the purposes of this summary, these items have been grouped into three technical areas: (1) the LAW and HLW glass algorithms as they pertain or apply to compositional regions anticipated to be processed through the WTP; (2) technical needs, requirements, and equipment to support mixing, sampling, and rheological measurements of both LAW and HLW wastes and melter feeds; and (3) the approaches and equipment required to support glass fabrication and subsequent characterization or analysis. The primary criterion for inclusion of documents in the review was based on applicability or relevancy of the literature to the intended scope as well as the need to provide a technical basis for the recommendations being made to WTP to support glass fabrication unit operations to be performed during this portion of the waste feed qualification program.

- $\quad$ LAW and HLW glass formulation algorithms and associated uncertainties

The glass formulation algorithms are used to determine the appropriate blend of glass forming materials to be added to each batch of pretreated feed entering the vitrification facility (HLW or LAW) to ensure all vitrification processing and disposal constraints are met. These algorithms have been developed, tested, and vetted over a contractually compliant limited set of Hanford tank waste compositions, and are expected to be developed over the life of the Hanford waste disposition program to cover the necessary ranges of waste to be processed. For the purposes of the waste feed qualification 
program, these algorithms will be approved for use for the particular staged waste campaign being tested in the waste feed qualification program. Although compositional gaps between the algorithms and the anticipated HLW and LAW compositional range to be processed through the WTP are known to exist, these gaps are currently being addressed through an integrated testing program.

- Mixing, sampling, and rheological measurements

Mixing/sampling will be important to the successful operation of the waste feed qualification process with respect to transferring materials from one vessel to another and sampling to ensure representative samples are obtained for the measurements required. Rheological measurements taken during the waste feed qualification program will be used to ensure that material can be transferred within the vitrification facilities (i.e., from vessel to vessel) or at least provide relative trends in the data that can be used to anticipate facility transfer problems or where concentration/dilution may be required. Good mixing and obtaining representative samples will be of utmost importance to support the qualification process. Of particular interest will be the impacts of particle size changes that may occur before (or during the measurement), soluble species and their impact on the measurement, and shear rate.

Based on the literature review, SRNL recommends that WTP use a low-shear, high speed mixer to ensure adequate mixing and subsequent subsampling for analytical or rheological measurements. Based on experience, SRNL recommends a remotable Haake $\mathrm{M} 5 / \mathrm{RV} 30$ rotoviscometer or similar to perform rheological measurements in support waste feed qualification efforts. This latter recommendation is based on SRNL operational experience to support DWPF qualification and radioactive sample characterization efforts, size or footprint, ease of remotability, and sample size requirements.

- Glass fabrication and analysis

With respect to HLW and LAW waste feed qualification efforts to support WTP operations, the conversion of the melter feed (representing feed from the MFV) to a glass product will occur in a laboratory setting - not a melter. More specifically, the melter feed will be converted to a glass product at a nominal temperature of $1150^{\circ} \mathrm{C}$. For WTP, the fabrication of the glass is essentially a confirmation step for the overall flowsheet.

Conversion of the melter feeds (both LAW and HLW) can be performed in any type of high temperature furnace (electrically-heated, gas fired, induction-based, etc). However, critical attributes of the furnace must include ease of integration into a cells environment (e.g., power and/or cooling services should be available), ability to attain temperatures up to the anticipated melting temperature of the glass (i.e., nominally $1150^{\circ} \mathrm{C}$ although higher facility melter temperatures have been contemplated $\left(1200^{\circ} \mathrm{C}\right)$ ), natural or forced convection to minimize thermal gradients in the working volume of the furnace, the working volume or capacity to hold a crucible size needed to fabricate the desired amount of glass, and a well-insulated shell to lower heat load or continuous thermal loss into the cells.

Based on SRNL experience supporting DWPF qualification efforts, a CM bottom loaded, elevator furnace (CM Furnaces, Inc, Model $1708 \mathrm{BL}$ or equivalent) is recommended. In addition, it is recommended that an inert Pt or Pt-alloy crucible be used to avoid cross- 
contamination due to crucible dissolution into the glass (as could occur with a ceramic based crucible). Compositional analysis of the resulting glass product could be accomplished either through use of a laser ablation technique coupled with Inductively Coupled Plasma - Atomic Emission Spectroscopy (ICP-AES) and Mass Spectroscopy (ICP-MS), which is currently the baseline analytical technique for facility operations or via a digestion/fusion preparation technique followed by ICP-AES and ICP-MS analyses.

With respect to inspection of the glass product, visual observations can provide a qualitative assessment that a glass product can be made with the incoming LAW or HLW wastes being qualified. However, the waste form compliance strategy is to rely on the glass algorithms to ensure both process and product quality constraints are acceptable. SRNL does not believe that the use of cooling curves to evaluate nepheline formation (or any other forms of crystallization) is required given waste feed qualification is not a demonstration of the HLW waste form compliance strategy. Glass property models have been (or will be) developed to ensure that the canister cooled glass meets the Waste Acceptance Product Specifications (DOE/EM-0093) during actual production and these same models will be used to guide the melter feed production during the glass fabrication unit operation.

\subsection{References}

1. Arakali, A.V., D.L. Banning, P.A. Benson, and D.A. Greer. 2011. Initial Data Quality Objectives for WTP Feed Acceptance Criteria, 24590-WTP-RPT-MGT-11-014, Revision 0, Bechtel, Richland, Washington.

2. Arakali, A.V., and J. Johnston. 2013. Integrated Sampling and Analysis Plan (ISAP), 24590LAB-PL-OP-12-0001, Revision 0, Waste Treatment Plan, Richland, Washington.

3. Benson, P.A. 2013. Updated Waste Feed Qualification Material and Analytical Flow Diagram, CCN 248476, River Protection Project, Waste Treatment Plant, Richland, Washington.

4. Benson, P.A., and T.G. Halverson. 2013. Waste Feed Qualification Program Plan, 24590WTP-PL-OP-12-0004, Revision 0, River Protection Project, Waste Treatment Plant, Richland, Washington.

5. Benson, P.A., J.R. Markillie, and R.W. Meinert. 2012. Batch Processing Methodology for High Level Waste Facility, 24590-HLW-RPT-OP-11-001, Revision A, River Protection Project, Waste Treatment Plant, Richland, Washington.

6. Brown, K.G., and R.L. Postles. 2006. SME Acceptability Determination for DWPF Process Control, WSRC-TR-95000364, Revision 5, Savannah River National Laboratory, Aiken, South Carolina.

7. Bruce, D.A. 2012. System Description for the Cesium Nitric Acid Recovery Process System CNP, 24590-PTF-3YD-CNP-00001, Revision 2, River Protection Project, Waste Treatment Plant, Richland, Washington. 
8. Crawford, C.L., D.M. Ferrara, R.F. Schumacher, and N.E. Bibler. 2001. Final report for Crucible Scale Vitrification of Pretreated C-106 Sludge Mixed with Secondary Wastes, WSRC-TR-2001-00252, Revision 0, Savannah River National Laboratory, Aiken, South Carolina.

9. Darby, R., 2001. Chemical Engineering Fluid Mechanics, 2nd edition, Marcel Dekker.

10. Edwards, T.B., D.K. Peeler, and K.M. Fox. 2006. The Nepheline Discriminator: Justification and DWPF PCCS Implementation Plan, WSRC-TR-2006-00014, Revision 0, Savannah River National Laboratory, Aiken, South Carolina.

11. Fox, K.M., T.B. Edwards, D.K. Peeler. 2006. Nepheline Formation Study for Sludge Batch 4 (SB4): Phase 3 Experimental Results, WSRC-TR-2006-00093, Revision 0, Washington Savannah River Company, Aiken, South Carolina.

12. Fox, K.M. and D.K. Peeler. 2007. Demonstration of Very High Aluminum Retention in Simulated HLW Glass, SRNL-PSE-2007-00231, Savannah River National Laboratory, Aiken, South Carolina.

13. Herman, C.C., D.E. Peeler, T.B. Edwards, M.E. Stone, and M. Smith. 2007. Process Changes to DWPF to Increase Throughput and Incorporate Salt Streams, MS\&T 2007, September 2007, Detroit, Michigan.

14. Herman, C.C., D.J. Adamson, D.T. Herman, D.K. Peeler, M.R. Poirier, S.H. Reboul, M.E. Stone, R.A. Peterson, J Chun, J.A. Fort, J.D. Vienna, and B.E. Wells. 2013. Preliminary Assessment of the Hanford Tank Waste Feed Acceptance and Product Qualification Programs, SRNL-STI-2012-00776/PNNL-22116, Revision 0, Savannah River National Laboratory, Aiken, South Carolina.

15. IEWO. 2011. Hanford Tank Waste Treatment and Immobilization Plant, IEWO M0SRV00028, Amendment 15, Waste Qualification Program Development, Scope of Work and Technical Requirements, SCT-M0SRV0028-00-012, Revision 0, River Protection Project, Waste Treatment Plant, Richland, Washington.

16. IEWO. 2012. Hanford Tank Waste Treatment and Immobilization Plant, IEWO M0SRV00028, Amendment 21, Waste Qualification Program Development, Scope of Work and Technical Requirements, SCT-M0SRV0028-00-012, Revision 0, River Protection Project, Waste Treatment Plant, Richland, Washington.

17. Jantzen, C.M., N.E. Bibler, D.C. Beam, C.L. Crawford, and M.A. Pickett. 1993. Characterization of the Defense Waste Processing Facility (DWPF) Environmental Assessment (EA) Glass Standard Reference Material, WSRC-TR-92-346, Revision 1, Westinghouse Savannah River Company, Aiken, South Carolina.

18. Kim, D.S., D.K. Peeler, and P. Hrma. 1995. "Effect of Crystallization on the Chemical Durability of Simulated Nuclear Waste Glasses," Environmental Issues and Waste Management Technologies in the Ceramic and Nuclear Industries, Ceramic Transaction, Volume 61, $177-185$. 
19. Kim, D. 2010. Chemical and Radionuclide Composition Projections for Immobilized High Level Waste Product Qualification, 24590-HLW-RPT-RT-08-001-01, Revision 1, River Protection Project, Waste Treatment Plant, Richland, Washington.

20. Kim, D. and J.D. Vienna. 2012. Preliminary ILAW Formulation Algorithm Description, 24590-LAW-RPT-RT-04-0003, Revision 1, River Protection Project, Waste Treatment Plant, Richland, Washington.

21. Koopman, D.C. Rheology Protocols for DWPF Samples, WSRC-RP-2004-00470, Revision 0, Savannah River National Laboratory, Aiken, South Carolina.

22. Kot, W.K. and I.L. Pegg. 2010. Glass Formulation Development and Testing for DWPF High- $\mathrm{Al}_{2} \mathrm{O}_{3} \mathrm{HLW}$ Sludges, VSL-10S1670-1, Revision 0, Vitreous State Laboratory, The Catholic University of America, Washington, DC.

23. Kruger, A.A. 2013. Advances in Glass Formulations for Hanford High-Aluminum, HighIron, and Enhanced Sulphate Management in HLW Streams, to be published in the proceedings of the Waste Management Conference, February 24 - 28, 2013, Phoenix, Arizona.

24. Kufahl, M. 2010. System Description for the HLW Melter Process System (HMP), 24590HLW-3YD-HMP-00001, Revision 4, River Protection Project, Waste Treatment Plant, Richland, Washington.

25. Li, H, J.D. Vienna, P. Hrma, D.E. Smith, and M.J. Schwieger. 1997. Nepheline Precipitation in High-Level Waste Glasses - Compositional Effects and Impact on the Waste Form Acceptability, Materials Research Society Proceedings, 465, pp. 261- 268.

26. Li, H., P. Hrma, J.D. Vienna, M. Qian, Y. Su, and D.E. Smith. 2003. Effects of $\mathrm{Al}_{2} \mathrm{O}_{3}, \mathrm{~B}_{2} \mathrm{O}_{3}$, $\mathrm{Na}_{2} \mathrm{O}$, and $\mathrm{SiO}_{2}$ on Nepheline Formation in Borosilicate Glasses: Chemical and Physical Correlations, Journal of Non-Crystalline Solids, 331, pp. $202-216$.

27. Markillie, J.R. and R.W. Meinert. 2011. Batch Processing Methodology for Low Activity Waste Facility, 24590-LAW-RPT-OP-11-001, Revision A, River Protection Project, Waste Treatment Plant, Richland, Washington.

28. Marra, J.C., K.M. Fox, D.K. Peeler, T.B. Edwards, A.L. Youchak, J.H. Gillam, J.D. Vienna, S.V. Stefanovsky, and A.S. Aloy. 2006. Glass Formulation Development to Support Melter Testing to Demonstrate Enhanced High Level Waste Throughput, WSRC-STI-2007-00236, Washington Savannah River Company, Aiken, South Carolina.

29. Marra, J.C., K.M. Fox, D.K. Peeler, T.B. Edwards, A.L. Youchak, J.H. Gillam, Jr., J.D. Vienna, S.V. Stefanovsky and A.S. Aloy. 2008. Glass Formulation Development in Support of Melter Testing to Demonstrate Enhanced High Level Waste Throughput, Scientific Basis for Nuclear Waste Management XXXI, edited by W.E. Lee, J.W. Roberts, N.C. Hyatt, and R.W. Grimes, Materials Research Society Symposium Proceedings 1107, Warrendale, PA.

30. Martinelli, P.M., E.J. Slaathaug, and D.M. Evans. 2012. System Description for the HLW Lag Storage and Feed Blending Process System (HLP), 24590-PTF-3YD-HLP-00001, Revision 2, River Protection Project, Waste Treatment Plant, Richland, Washington. 
31. Muller I.S., I.L. Pegg, and I. Joseph. 2013. Test Plan: Enhanced LAW Glass PropertyComposition Models, Phase 2, VSL-13T3050-1, Revision 0, Vitreous State Laboratory, Washington DC.

32. Nelson, J.L., J.D. Vienna, K. Abel, and D. Kim. 2007. ILAW Product Qualification Report for the Hanford Tank Waste Treatment and Immobilization Plant, 24590-LAW-RPT-RT-05001, Revision. 0, Waste Treatment Plant, Richland, Washington.

33. Nelson, J.L. and J.D. Vienna. 2009. IHLW Waste Form Compliance Plan for the Hanford Tank Waste Treatment and Immobilization Plant, 24590-HLW-PL-RT-07-0001, Revision 3, Waste Treatment Plant, Richland, Washington.

34. Nelson. J.L., D. Kim, L.L. Petkus, J.D. Vienna. 2011. ILAW Product Compliance Plan, 24590-WTP-PL-RT-03-001, Revision. 5, Waste Treatment Plant, Richland, Washington.

35. Nelson, J.L. 2010. IHLW Waste Form Qualification Report for the Hanford Tank Waste Treatment and Immobilization Plant - Introduction, 24590-HLW-RPT-RT-08-001, Revision 0 , Waste Treatment Plant, Richland, Washington.

36. Olson, J.W. 2011. ICD 19 - Interface Control Document for Waste Feed, 24590-WTP-ICDMG-01-019, Revision 5, Waste Treatment Plant, Richland, Washington.

37. Pareizs, J.M. and C.L. Crawford. 2013. Sludge Washing and Demonstration of the DWPF Flowsheet in the SRNL Shielded Cell for Sludge Batch 8 Qualification, SRNL-STI-201300116, Revision 0, Savannah River National Laboratory, Aiken, South Carolina.

38. Pareizs, JM, A.L. Billings, S.H. Reboul, D.P. Lambert, and D.R. Click. 2011. Sludge Batch $7 b$ Qualification Activities with SRS Tank Farm Sludge, SRNL-STI-2011-00548, Revision 0, Savannah River National Laboratory, Aiken, South Carolina.

39. Parker, M.Y. 2010. System Description for the System LMP, Low Activity Waste Melter, 24590-LAW-3YD-LMP-00001, Revision 3, River Protection Project, Waste Treatment Plant, Richland, Washington.

40. Peeler, D.K., T.B. Edwards, I.A. Reamer, and R.J. Workman. 2005. Nepheline Formation Study for Sludge Batch 4 (SB4): Phase 1 Experimental Results, WSRC-TR-2005-00371, Revision 0, Westinghouse Savannah River Company, Aiken, South Carolina.

41. Peeler, D.K., T.B. Edwards, D.R. Best, I.A. Reamer, and R.J. Workman. 2006. Nepheline Formation Study for Sludge Batch 4 (SB4): Phase 2 Experimental Results, WSRC-TR-200600006, Revision 0, Washington Savannah River Company, Aiken, South Carolina.

42. Peeler, D.K., C.C. Herman, T.B. Edwards, R.J. Workman, I.A. Reamer, J.D. Vienna, J.V. Crum, D.E. Smith, and D.S. Kim. 2002. Development of High Waste Loading Glasses for Advanced Melter Technologies, WSRC-TR-2002-00426, Westinghouse Savannah River Company, Aiken, South Carolina.

43. Peeler, D.K., E.K. Hansen, C.C. Herman, S.L. Marra, and W.R. Wilmarth. 2012. SRNL Phase 1 Assessment of the WTP Waste Qualification Program, SRNL-STI-2011-00723, Revision 0, Savannah River National Laboratory, Aiken, South Carolina. 
44. Peeler, D.K., D.J. Adamson, C.J. Bannochie, A.D. Cozzi, R.E. Eibling, M.S. Hay, E.K. Hansen, D.T. Herman, C.J. Martino, C.A. Nash, F.M. Pennebaker, M.R. Poirier, S.H. Reboul, M.E. Stone, K.M. Taylor-Pashow, T.L. White, and W.R. Wilmarth. 2012. SRNL Phase 1 Assessment of the WAC/DQO and Unit Operations for the WTP Waste Qualification Program, SRNL-STI-2011-00724, Revision 0, Savannah River National Laboratory, Aiken, South Carolina.

45. Raszewski, F.C., T.B. Edwards, and D.K. Peeler. 2008. Enhanced DOE High Level Waste Melter Throughput Studies: SRNL Glass Selection Strategy, WSRC-STI-2007-00652, Washington Savannah River Company, Aiken, South Carolina.

46. Slaathaug, E.J. 2011. Specification 12 - Procedure to Determine the Waste Feed Treatment Approach, River Protection Project, Waste Treatment Plant, 24590-WTP-RPT-PET-11-002, Revision A.

47. Smith G.L. and K. Prindiville. 2002. Guidelines for Performing Chemical, Physical, and Rheological Properties Measurements, 24590-WTP-GPG-RTD-001, Revision 0, River Protection Project, Waste Treatment Plant, Richland, Washington.

48. Stone, M.E.. 2012. Evaluation of Methods to Measure Hydrogen Generation Rate in a Shielded Cell Environment and a Method Recommendation, SRNL-STI-2012-00511, Revision 0, Savannah River National Laboratory, Aiken, South Carolina.

49. Vienna, J.D. and D. Kim. 2008. Preliminary IHLW Formulation Algorithm Description, 24590-HLW-RPT-RT-05-001, Revision 0, River Protection Project, Waste Treatment Plant, Richland, Washington.

50. Vienna, J.D., D.S. Kim, M.J. Schweiger, J.S. McCloy, J. Matyas, G.F. Piepel, and S.K. Cooley. 2013. Test Plan: Enhanced Hanford Waste Glass Models, TR-EWG-00001, Revision 0, Pacific Northwest National Laboratory, Richland, Washington.

51. Waste Acceptance Product Specifications for Vitrified High level Waste Forms, DOE/EM0093, Revision 2, United States Department of Energy, Office of Environmental Management. 
SRNL-STI-2013-00187

Revision 0

Appendix A

Documents Included in the Literature Review 


\begin{tabular}{|c|c|c|c|c|c|c|c|c|c|}
\hline $\begin{array}{l}\text { Reference } \\
\#\end{array}$ & Reference & Comments & $\begin{array}{c}\text { Glass } \\
\text { Algorithms }\end{array}$ & $\begin{array}{c}\text { Mixing } \\
\text { and } \\
\text { Sampling } \\
\end{array}$ & Rheology & $\begin{array}{c}\text { Heat of } \\
\text { Hydration }\end{array}$ & $\begin{array}{c}\text { Glass } \\
\text { Fabrication }\end{array}$ & $\begin{array}{l}\text { Cooling } \\
\text { Curves }\end{array}$ & HGR \\
\hline 3 & $\begin{array}{l}\text { Benson, P.A. } 2013 . \\
\text { Updated Waste Feed } \\
\text { Qualification Material } \\
\text { and Analytical Flow } \\
\text { Diagram, CCN } \\
\text { 248472, River } \\
\text { Protection Project, } \\
\text { Waste Treatment } \\
\text { Plant, Richland, } \\
\text { Washington. }\end{array}$ & $\begin{array}{l}\text { Provides most } \\
\text { recent } \\
\text { schematic of } \\
\text { HLW and LAW } \\
\text { Glass } \\
\text { Fabrication } \\
\text { Unit Operations } \\
\text { under the Waste } \\
\text { Feed } \\
\text { Qualification } \\
\text { Program } \\
\end{array}$ & $\mathrm{X}$ & & $\mathrm{X}$ & & $\mathrm{X}$ & & $\mathrm{X}$ \\
\hline 4 & $\begin{array}{l}\text { Benson, P.A., and } \\
\text { T.G. Halverson. } 2013 . \\
\text { Waste Feed } \\
\text { Qualification Program } \\
\text { Plan, 24590-WTP-PL- } \\
\text { OP-12-0004, Revision } \\
\text { 0, River Protection } \\
\text { Project, Waste } \\
\text { Treatment Plant, } \\
\text { Richland, Washington. }\end{array}$ & $\begin{array}{l}\text { Document } \\
\text { describes waste } \\
\text { feed } \\
\text { qualification } \\
\text { program for } \\
\text { WTP }\end{array}$ & $\mathrm{X}$ & $\mathrm{X}$ & $\mathrm{X}$ & $\mathrm{X}$ & $\mathrm{X}$ & $\mathrm{X}$ & $\mathrm{X}$ \\
\hline 5 & $\begin{array}{l}\text { Benson, P.A., J.R. } \\
\text { Markillie, and R.W. } \\
\text { Meinert. 2012. Batch } \\
\text { Processing } \\
\text { Methodology for High } \\
\text { Level Waste Facility, } \\
\text { 24590-HLW-RPT-OP- } \\
\text { 11-001, Revision A, } \\
\text { River Protection } \\
\text { Project, Waste } \\
\text { Treatment Plant, } \\
\text { Richland, Washington } \\
\end{array}$ & $\begin{array}{l}\text { Document } \\
\text { describes the } \\
\text { approach the } \\
\text { WTP operations } \\
\text { team will } \\
\text { implement use } \\
\text { of the glass } \\
\text { formulation } \\
\text { algorithm }\end{array}$ & $\mathrm{X}$ & & & & $\mathrm{X}$ & & \\
\hline 8 & Crawford, C.L., D.M. & Document & & & & $\mathrm{X}$ & & & \\
\hline
\end{tabular}




\begin{tabular}{|c|c|c|c|c|c|c|c|c|c|}
\hline $\begin{array}{l}\text { Reference } \\
\#\end{array}$ & Reference & Comments & $\begin{array}{c}\text { Glass } \\
\text { Algorithms }\end{array}$ & $\begin{array}{c}\text { Mixing } \\
\text { and } \\
\text { Sampling } \\
\end{array}$ & Rheology & $\begin{array}{c}\text { Heat of } \\
\text { Hydration }\end{array}$ & $\begin{array}{c}\text { Glass } \\
\text { Fabrication }\end{array}$ & $\begin{array}{l}\text { Cooling } \\
\text { Curves }\end{array}$ & HGR \\
\hline & $\begin{array}{l}\text { Ferrara, R.F. } \\
\text { Schumacher, and N.E. } \\
\text { Bibler. 2001. Final } \\
\text { report for Crucible } \\
\text { Scale Vitrification of } \\
\text { Pretreated C-106 } \\
\text { Sludge Mixed with } \\
\text { Secondary Wastes, } \\
\text { WSRC-TR-2001- } \\
\text { 00252, Revision 0, } \\
\text { Savannah River } \\
\text { National Laboratory, } \\
\text { Aiken, South Carolina. }\end{array}$ & $\begin{array}{l}\text { provides } \\
\text { specific insight } \\
\text { into heat of } \\
\text { hydration or } \\
\text { temperature rise } \\
\text { from laboratory } \\
\text { testing due to } \\
\text { mixing }\end{array}$ & & & & & & & \\
\hline 10 & $\begin{array}{l}\text { Edwards, T.B., D.K. } \\
\text { Peeler, and K.M. Fox. } \\
\text { 2006. The Nepheline } \\
\text { Discriminator: } \\
\text { Justification and } \\
\text { DWPF PCCS } \\
\text { Implementation Plan, } \\
\text { WSRC-TR-2006- } \\
\text { 00014, Revision 0, } \\
\text { Savannah River } \\
\text { National Laboratory, } \\
\text { Aiken, South Carolina. }\end{array}$ & $\begin{array}{l}\text { Document } \\
\text { provides } \\
\text { technical basis } \\
\text { for the } \\
\text { implementation } \\
\text { of the nepheline } \\
\text { discriminator } \\
\text { into DWPF's } \\
\text { process control }\end{array}$ & & & & & & $\mathrm{X}$ & \\
\hline 11 & $\begin{array}{l}\text { Fox, K.M., T.B. } \\
\text { Edwards, D.K. Peeler. } \\
\text { 2006. Nepheline } \\
\text { Formation Study for } \\
\text { Sludge Batch } 4 \text { (SB4): } \\
\text { Phase } 3 \text { Experimental } \\
\text { Results, WSRC-TR- } \\
\text { 2006-00093, Revision } \\
\text { 0, Washington }\end{array}$ & $\begin{array}{l}\text { Document } \\
\text { provides insight } \\
\text { into nepheline } \\
\text { formation and } \\
\text { impact on glass } \\
\text { durability } \\
\text { (specific to } \\
\text { Sludge Batch 4) }\end{array}$ & & & & & & $\mathrm{X}$ & \\
\hline
\end{tabular}




\begin{tabular}{|c|c|c|c|c|c|c|c|c|c|}
\hline $\begin{array}{l}\text { Reference } \\
\#\end{array}$ & Reference & Comments & $\begin{array}{c}\text { Glass } \\
\text { Algorithms }\end{array}$ & $\begin{array}{c}\text { Mixing } \\
\text { and } \\
\text { Sampling }\end{array}$ & Rheology & $\begin{array}{c}\text { Heat of } \\
\text { Hydration }\end{array}$ & $\begin{array}{c}\text { Glass } \\
\text { Fabrication }\end{array}$ & $\begin{array}{l}\text { Cooling } \\
\text { Curves }\end{array}$ & HGR \\
\hline & $\begin{array}{l}\text { Savannah River } \\
\text { Company, Aiken, } \\
\text { South Carolina. }\end{array}$ & & & & & & & & \\
\hline 17 & $\begin{array}{l}\text { Jantzen, CM, NE } \\
\text { Bibler, DC Beam, CL } \\
\text { Crawford, and MA } \\
\text { Pickett. 1993. } \\
\text { Characterization of } \\
\text { the Defense Waste } \\
\text { Processing Facility } \\
\text { (DWPF) } \\
\text { Environmental } \\
\text { Assessment (EA) Glass } \\
\text { Standard Reference } \\
\text { Material, WSRC-TR- } \\
\text { 92-346, Revision 1, } \\
\text { Westinghouse } \\
\text { Savannah River } \\
\text { Company, Aiken, } \\
\text { South Carolina. }\end{array}$ & $\begin{array}{l}\text { Document } \\
\text { provides } \\
\text { technical basis } \\
\text { for durability } \\
\text { response of EA } \\
\text { glass which is } \\
\text { used as the } \\
\text { HLW } \\
\text { performance } \\
\text { standard }\end{array}$ & $\mathrm{X}$ & & & & & $X$ & \\
\hline 18 & $\begin{array}{l}\text { Kim, D.S., D.K. } \\
\text { Peeler, and P. Hrma. } \\
\text { 1995. "Effect of } \\
\text { Crystallization on the } \\
\text { Chemical Durability } \\
\text { of Simulated Nuclear } \\
\text { Waste Glasses," } \\
\text { Environmental Issues } \\
\text { and Waste } \\
\text { Management } \\
\text { Technologies in the } \\
\text { Ceramic and Nuclear } \\
\text { Industries, Ceramic } \\
\text { Transaction, Volume }\end{array}$ & $\begin{array}{l}\text { Document } \\
\text { provides insight } \\
\text { into the impact } \\
\text { of nepheline } \\
\text { and other } \\
\text { crystalline } \\
\text { phase formation } \\
\text { on glass } \\
\text { durability }\end{array}$ & & & & & & $\mathrm{X}$ & \\
\hline
\end{tabular}




\begin{tabular}{|c|c|c|c|c|c|c|c|c|c|}
\hline $\begin{array}{l}\text { Reference } \\
\#\end{array}$ & Reference & Comments & $\begin{array}{c}\text { Glass } \\
\text { Algorithms }\end{array}$ & $\begin{array}{c}\text { Mixing } \\
\text { and } \\
\text { Sampling } \\
\end{array}$ & Rheology & $\begin{array}{c}\text { Heat of } \\
\text { Hydration }\end{array}$ & $\begin{array}{c}\text { Glass } \\
\text { Fabrication }\end{array}$ & $\begin{array}{l}\text { Cooling } \\
\text { Curves }\end{array}$ & HGR \\
\hline & $61,177-185$ & & & & & & & & \\
\hline 19 & $\begin{array}{l}\text { Kim, D. 2010. } \\
\text { Chemical and } \\
\text { Radionuclide } \\
\text { Composition } \\
\text { Projections for } \\
\text { Immobilized High } \\
\text { Level Waste Product } \\
\text { Qualification, 24590- } \\
\text { HLW-RPT-RT-08- } \\
\text { 001-01, Revision 1, } \\
\text { River Protection } \\
\text { Project, Waste } \\
\text { Treatment Plant, } \\
\text { Richland, Washington. }\end{array}$ & $\begin{array}{l}\text { Document } \\
\text { provides basis } \\
\text { for LAW waste } \\
\text { characterization } \\
\text { results over } \\
\text { which current } \\
\text { HLW model } \\
\text { have been } \\
\text { developed }\end{array}$ & $\mathrm{X}$ & & & & & & \\
\hline 20 & $\begin{array}{l}\text { Kim, D. and J.D. } \\
\text { Vienna. 2012. } \\
\text { Preliminary ILAW } \\
\text { Formulation } \\
\text { Algorithm } \\
\text { Description, 24590- } \\
\text { LAW-RPT-RT-04- } \\
\text { 0003, Revision 1, } \\
\text { River Protection } \\
\text { Project, Waste } \\
\text { Treatment Plant, } \\
\text { Richland, Washington. }\end{array}$ & $\begin{array}{l}\text { Document } \\
\text { provides } \\
\text { technical basis } \\
\text { of current LAW } \\
\text { glass algorithms }\end{array}$ & $\mathrm{X}$ & & & & & & \\
\hline 21 & $\begin{array}{l}\text { Koopman, D.C. } \\
\text { Rheology protocols for } \\
\text { DWPF Samples, } \\
\text { WSRC-RP-2004- } \\
\text { 00470, Revision 0, } \\
\text { Savannah River } \\
\text { National Laboratory, }\end{array}$ & & & $\mathrm{X}$ & $\bar{X}$ & & & & \\
\hline
\end{tabular}




\begin{tabular}{|c|c|c|c|c|c|c|c|c|c|}
\hline $\begin{array}{l}\text { Reference } \\
\#\end{array}$ & Reference & Comments & $\begin{array}{c}\text { Glass } \\
\text { Algorithms }\end{array}$ & $\begin{array}{l}\text { Mixing } \\
\text { and } \\
\text { Sampling }\end{array}$ & Rheology & $\begin{array}{c}\text { Heat of } \\
\text { Hydration }\end{array}$ & $\begin{array}{c}\text { Glass } \\
\text { Fabrication }\end{array}$ & $\begin{array}{l}\text { Cooling } \\
\text { Curves }\end{array}$ & HGR \\
\hline & Aiken, South Carolina. & & & & & & & & \\
\hline 24 & $\begin{array}{l}\text { Kufahl, M. } 2010 . \\
\text { System Description for } \\
\text { the HLW Melter } \\
\text { Process System } \\
\text { (HMP), 24590-HLW- } \\
\text { 3YD-HMP-00001, } \\
\text { Revision 4, River } \\
\text { Protection Project, } \\
\text { Waste Treatment } \\
\text { Plant, Richland, } \\
\text { Washington. }\end{array}$ & $\begin{array}{l}\text { Document } \\
\text { provides } \\
\text { nominal } \\
\text { operating } \\
\text { conditions for } \\
\text { the HLW } \\
\text { melters }\end{array}$ & & & & & $\mathrm{X}$ & & \\
\hline 25 & $\begin{array}{l}\text { Li, H., J.D. Vienna, P. } \\
\text { Hrma, D.E. Smith, and } \\
\text { M.J. Schwieger. } 1997 . \\
\text { Nepheline } \\
\text { Precipitation in High- } \\
\text { Level Waste Glasses - } \\
\text { Compositional Effects } \\
\text { and Impact on the } \\
\text { Waste Form } \\
\text { Acceptability, } \\
\text { Materials Research } \\
\text { Society Proceedings, } \\
\text { 465, pp. 261-268. }\end{array}$ & $\begin{array}{l}\text { Document } \\
\text { provides insight } \\
\text { into nepheline } \\
\text { formation and } \\
\text { impact on glass } \\
\text { durability }\end{array}$ & & & & & & $\mathrm{X}$ & \\
\hline 26 & $\begin{array}{l}\mathrm{Li}, \mathrm{H} ., \text { P. Hrma, J.D. } \\
\text { Vienna, M. Qian, Y. } \\
\mathrm{Su} \text {, and D.E. Smith. } \\
\text { 2003. Effects of } \mathrm{Al}_{2} \mathrm{O}_{3} \text {, } \\
\mathrm{B}_{2} \mathrm{O}_{3}, \mathrm{Na}_{2} \mathrm{O} \text {, and } \mathrm{SiO}_{2} \\
\text { on Nepheline } \\
\text { Formation in } \\
\text { Borosilicate Glasses: } \\
\text { Chemical and }\end{array}$ & $\begin{array}{l}\text { Document } \\
\text { provides } \\
\text { technical basis } \\
\text { into nepheline } \\
\text { formation and } \\
\text { impact on glass } \\
\text { durability }\end{array}$ & & & & & & $\mathrm{X}$ & \\
\hline
\end{tabular}




\begin{tabular}{|c|c|c|c|c|c|c|c|c|c|}
\hline $\begin{array}{l}\text { Reference } \\
\#\end{array}$ & Reference & Comments & $\begin{array}{c}\text { Glass } \\
\text { Algorithms }\end{array}$ & $\begin{array}{l}\text { Mixing } \\
\text { and } \\
\text { Sampling }\end{array}$ & Rheology & $\begin{array}{c}\text { Heat of } \\
\text { Hydration }\end{array}$ & $\begin{array}{c}\text { Glass } \\
\text { Fabrication }\end{array}$ & $\begin{array}{l}\text { Cooling } \\
\text { Curves }\end{array}$ & HGR \\
\hline & $\begin{array}{l}\text { Physical Correlations, } \\
\text { Journal of Non- } \\
\text { Crystalline Solids, } \\
\text { 331, pp. } 202-216 .\end{array}$ & & & & & & & & \\
\hline 27 & $\begin{array}{l}\text { Markillie, J.R. and } \\
\text { R.W. Meinert. } 2011 . \\
\text { Batch Processing } \\
\text { Methodology for Low } \\
\text { Activity Waste } \\
\text { Facility, 24590-LAW- } \\
\text { RPT-OP-11-001, } \\
\text { Revision A, River } \\
\text { Protection Project, } \\
\text { Waste Treatment } \\
\text { Plant, Richland, } \\
\text { Washington }\end{array}$ & $\begin{array}{l}\text { Document } \\
\text { describes the } \\
\text { approach the } \\
\text { WTP operations } \\
\text { team will } \\
\text { implement use } \\
\text { of the glass } \\
\text { formulation } \\
\text { algorithm }\end{array}$ & $\mathrm{X}$ & & & & $\mathrm{X}$ & & \\
\hline 30 & $\begin{array}{l}\text { Martinelli, P.M., E.J. } \\
\text { Slaathaug, and D.M. } \\
\text { Evans. 2012. System } \\
\text { Description for the } \\
\text { HLW Lag Storage and } \\
\text { Feed Blending } \\
\text { Process System (HLP), } \\
\text { 24590-PTF-3YD- } \\
\text { HLP-0001, Revision } \\
\text { 2, River Protection } \\
\text { Project, Waste } \\
\text { Treatment Plant, } \\
\text { Richland, Washington. }\end{array}$ & $\begin{array}{l}\text { Document } \\
\text { provides details } \\
\text { on facility } \\
\text { operations } \\
\text { associated with } \\
\text { mixing of } \\
\text { caustic sludge } \\
\text { and acidic CNP } \\
\text { stream }\end{array}$ & & & & $\mathrm{X}$ & & & \\
\hline 31 & $\begin{array}{l}\text { Muller I.S., I.L. Pegg, } \\
\text { and I. Joseph. } 2013 . \\
\text { Test Plan: Enhanced } \\
\text { LAW Glass Property- } \\
\text { Composition Models, }\end{array}$ & $\begin{array}{l}\text { Document } \\
\text { describes } \\
\text { approach to } \\
\text { enhance the } \\
\text { LAW glass }\end{array}$ & $\mathrm{X}$ & & & & & & \\
\hline
\end{tabular}




\begin{tabular}{|c|c|c|c|c|c|c|c|c|c|}
\hline $\begin{array}{l}\text { Reference } \\
\#\end{array}$ & Reference & Comments & $\begin{array}{c}\text { Glass } \\
\text { Algorithms }\end{array}$ & $\begin{array}{c}\text { Mixing } \\
\text { and } \\
\text { Sampling } \\
\end{array}$ & Rheology & $\begin{array}{c}\text { Heat of } \\
\text { Hydration }\end{array}$ & $\begin{array}{c}\text { Glass } \\
\text { Fabrication }\end{array}$ & $\begin{array}{l}\text { Cooling } \\
\text { Curves }\end{array}$ & HGR \\
\hline & $\begin{array}{l}\text { Phase 2, VSL- } \\
\text { 13T3050-1, Revision } \\
\text { 0, Vitreous State } \\
\text { Laboratory, } \\
\text { Washington DC. }\end{array}$ & $\begin{array}{l}\text { models to } \\
\text { compositional } \\
\text { regions } \\
\text { anticipated to } \\
\text { be processed } \\
\text { through WTP }\end{array}$ & & & & & & & \\
\hline 32 & $\begin{array}{l}\text { Nelson, J.L., J.D. } \\
\text { Vienna, K. Abel, and } \\
\text { D. Kim. 2007. ILAW } \\
\text { Product Qualification } \\
\text { Report for the Hanford } \\
\text { Tank Waste Treatment } \\
\text { and Immobilization } \\
\text { Plant, 24590-LAW- } \\
\text { RPT-RT-05-001, } \\
\text { Revision. 0, Waste } \\
\text { Treatment Plant, } \\
\text { Richland, Washington. }\end{array}$ & $\begin{array}{l}\text { Document } \\
\text { describes the } \\
\text { WTP product } \\
\text { qualification } \\
\text { requirements } \\
\text { for ILAW waste } \\
\text { form }\end{array}$ & $\mathrm{X}$ & & & & & & \\
\hline 35 & $\begin{array}{l}\text { Nelson, J.L. } 2010 . \\
\text { IHLW Waste Form } \\
\text { Qualification Report } \\
\text { for the Hanford Tank } \\
\text { Waste Treatment and } \\
\text { Immobilization Plant- } \\
\text { Introduction, 24590- } \\
\text { HLW-RPT-RT-08- } \\
\text { 001, Revision 0, } \\
\text { Waste Treatment } \\
\text { Plant, Richland, } \\
\text { Washington. }\end{array}$ & $\begin{array}{l}\text { Document } \\
\text { describes the } \\
\text { WTP product } \\
\text { qualification } \\
\text { requirements } \\
\text { for IHLW waste } \\
\text { form }\end{array}$ & $\mathrm{X}$ & & & & & & \\
\hline 37 & $\begin{array}{l}\text { Pareizs, J.M. and C.L. } \\
\text { Crawford. } 2013 . \\
\text { Sludge Washing and } \\
\text { Demonstration of the }\end{array}$ & $\begin{array}{l}\text { Document } \\
\text { describes } \\
\text { SRNL's } \\
\text { protocols used }\end{array}$ & & $\mathrm{X}$ & $X$ & & $\mathrm{X}$ & & \\
\hline
\end{tabular}




\begin{tabular}{|c|c|c|c|c|c|c|c|c|c|}
\hline $\begin{array}{l}\text { Reference } \\
\#\end{array}$ & Reference & Comments & $\begin{array}{c}\text { Glass } \\
\text { Algorithms }\end{array}$ & $\begin{array}{c}\text { Mixing } \\
\text { and } \\
\text { Sampling } \\
\end{array}$ & Rheology & $\begin{array}{c}\text { Heat of } \\
\text { Hydration }\end{array}$ & $\begin{array}{c}\text { Glass } \\
\text { Fabrication }\end{array}$ & $\begin{array}{l}\text { Cooling } \\
\text { Curves }\end{array}$ & HGR \\
\hline & $\begin{array}{l}\text { DWPF Flowsheet in } \\
\text { the SRNL Shielded } \\
\text { Cell for Sludge Batch } \\
8 \text { Qualification, } \\
\text { SRNL-STI-2013- } \\
\text { 00116, Revision 0, } \\
\text { Savannah River } \\
\text { National Laboratory, } \\
\text { Aiken, South Carolina. }\end{array}$ & $\begin{array}{l}\text { to support waste } \\
\text { qualification for } \\
\text { DWPF (SB8 } \\
\text { specific) }\end{array}$ & & & & & & & \\
\hline 38 & $\begin{array}{l}\text { Pareizs, J.M., A.L. } \\
\text { Billings, S.H. Reboul, } \\
\text { D.P. Lambert, and } \\
\text { D.R. Click. } 2011 . \\
\text { Sludge Batch } 7 b \\
\text { Qualification } \\
\text { Activities with SRS } \\
\text { Tank Farm Sludge, } \\
\text { SRNL-STI-2011- } \\
\text { 00548, Revision 0, } \\
\text { Savannah River } \\
\text { National Laboratory, } \\
\text { Aiken, South Carolina. }\end{array}$ & $\begin{array}{l}\text { Document } \\
\text { describes } \\
\text { SRNL's } \\
\text { protocols used } \\
\text { to support waste } \\
\text { qualification for } \\
\text { DWPF (SB7b } \\
\text { specific) }\end{array}$ & & $\mathrm{X}$ & $\mathrm{X}$ & & $\mathrm{X}$ & & \\
\hline 39 & $\begin{array}{l}\text { Parker, M.Y. } 2010 . \\
\text { System Description for } \\
\text { the System LMP, Low } \\
\text { Activity Waste Melter, } \\
\text { 24590-LAW-3YD- } \\
\text { LMP-00001, Revision } \\
\text { 3, River Protection } \\
\text { Project, Waste } \\
\text { Treatment Plant, } \\
\text { Richland, Washington. }\end{array}$ & $\begin{array}{l}\text { Document } \\
\text { provides } \\
\text { nominal } \\
\text { operating } \\
\text { conditions for } \\
\text { the LAW } \\
\text { melters }\end{array}$ & & & & & $\mathrm{X}$ & & \\
\hline 40 & $\begin{array}{l}\text { Peeler, D.K., T.B. } \\
\text { Edwards, I.A. Reamer, }\end{array}$ & $\begin{array}{l}\text { Document } \\
\text { describes the }\end{array}$ & & & & & & $\mathrm{X}$ & \\
\hline
\end{tabular}




\begin{tabular}{|c|c|c|c|c|c|c|c|c|c|}
\hline $\begin{array}{l}\text { Reference } \\
\#\end{array}$ & Reference & Comments & $\begin{array}{c}\text { Glass } \\
\text { Algorithms }\end{array}$ & $\begin{array}{c}\text { Mixing } \\
\text { and } \\
\text { Sampling }\end{array}$ & Rheology & $\begin{array}{c}\text { Heat of } \\
\text { Hydration }\end{array}$ & $\begin{array}{c}\text { Glass } \\
\text { Fabrication }\end{array}$ & $\begin{array}{l}\text { Cooling } \\
\text { Curves }\end{array}$ & HGR \\
\hline & $\begin{array}{l}\text { and R.J. Workman. } \\
\text { 2005. Nepheline } \\
\text { Formation Study for } \\
\text { Sludge Batch } 4 \text { (SB4): } \\
\text { Phase } 1 \text { Experimental } \\
\text { Results, WSRC-TR- } \\
\text { 2005-00371, Revision } \\
\text { 0, Westinghouse } \\
\text { Savannah River } \\
\text { Company, Aiken, } \\
\text { South Carolina. }\end{array}$ & $\begin{array}{l}\text { formation of } \\
\text { nepheline and } \\
\text { impact on glass } \\
\text { durability }\end{array}$ & & & & & & & \\
\hline 41 & $\begin{array}{l}\text { Peeler, D.K., T.B. } \\
\text { Edwards, D.R. Best, } \\
\text { I.A. Reamer, and R.J. } \\
\text { Workman. 2006. } \\
\text { Nepheline Formation } \\
\text { Study for Sludge Batch } \\
4 \text { (SB4): Phase } 2 \\
\text { Experimental Results, } \\
\text { WSRC-TR-2006- } \\
\text { 00006, Revision 0, } \\
\text { Washington Savannah } \\
\text { River Company, } \\
\text { Aiken, South Carolina. }\end{array}$ & $\begin{array}{l}\text { Document } \\
\text { describes the } \\
\text { formation of } \\
\text { nepheline and } \\
\text { impact on glass } \\
\text { durability }\end{array}$ & & & & & & $\bar{X}$ & \\
\hline 47 & $\begin{array}{l}\text { Smith G.L. and K. } \\
\text { Prindiville. } 2002 . \\
\text { Guidelines for } \\
\text { Performing Chemical, } \\
\text { Physical, and } \\
\text { Rheological } \\
\text { Properties } \\
\text { Measurements, 24590- } \\
\text { WTP-GPG-RTD-001, } \\
\text { Revision 0, River }\end{array}$ & $\begin{array}{l}\text { Document } \\
\text { provides } \\
\text { guidelines for } \\
\text { performing } \\
\text { rheological } \\
\text { measurements } \\
\text { for WTP }\end{array}$ & & $\mathrm{X}$ & $\mathrm{X}$ & & & & \\
\hline
\end{tabular}




\begin{tabular}{|c|c|c|c|c|c|c|c|c|c|}
\hline $\begin{array}{l}\text { Reference } \\
\#\end{array}$ & Reference & Comments & $\begin{array}{c}\text { Glass } \\
\text { Algorithms }\end{array}$ & $\begin{array}{c}\text { Mixing } \\
\text { and } \\
\text { Sampling } \\
\end{array}$ & Rheology & $\begin{array}{l}\text { Heat of } \\
\text { Hydration }\end{array}$ & $\begin{array}{c}\text { Glass } \\
\text { Fabrication }\end{array}$ & $\begin{array}{l}\text { Cooling } \\
\text { Curves }\end{array}$ & HGR \\
\hline & $\begin{array}{l}\text { Protection Project, } \\
\text { Waste Treatment } \\
\text { Plant, Richland, } \\
\text { Washington }\end{array}$ & & & & & & & & \\
\hline 48 & $\begin{array}{l}\text { Stone, M.E.. } 2012 . \\
\text { Evaluation of Methods } \\
\text { to Measure Hydrogen } \\
\text { Generation Rate in a } \\
\text { Shielded Cell } \\
\text { Environment and a } \\
\text { Method } \\
\text { Recommendation, } \\
\text { SRNL-STI-2012- } \\
\text { 00511, Revision 0, } \\
\text { Savannah River } \\
\text { National Laboratory, } \\
\text { Aiken, South Carolina. }\end{array}$ & $\begin{array}{l}\text { Document } \\
\text { describes the } \\
\text { literature survey } \\
\text { performed on } \\
\text { HGR } \\
\text { measurements } \\
\text { in support of } \\
\text { the WTP } \\
\text { qualification } \\
\text { program }\end{array}$ & & & & & & & $\mathrm{X}$ \\
\hline 49 & $\begin{array}{l}\text { Vienna, J.D. and D. } \\
\text { Kim. 2008. } \\
\text { Preliminary IHLW } \\
\text { Formulation } \\
\text { Algorithm } \\
\text { Description, 24590- } \\
\text { HLW-RPT-RT-05- } \\
\text { 001, Revision 0, River } \\
\text { Protection Project, } \\
\text { Waste Treatment } \\
\text { Plant, Richland, } \\
\text { Washington. } \\
\end{array}$ & $\begin{array}{l}\text { Document } \\
\text { provides } \\
\text { technical basis } \\
\text { of current HLW } \\
\text { glass algorithms }\end{array}$ & $\mathrm{X}$ & & & & & & \\
\hline 50 & $\begin{array}{l}\text { Vienna, J.D., D.S. } \\
\text { Kim, M.J. Schweiger, } \\
\text { J.S. McCloy, J. } \\
\text { Matyas, G.F. Piepel, } \\
\text { and S.K. Cooley. }\end{array}$ & $\begin{array}{l}\text { Document } \\
\text { describes } \\
\text { approach to } \\
\text { enhance the } \\
\text { LAW and HLW }\end{array}$ & $\mathrm{X}$ & & & & & & \\
\hline
\end{tabular}




\begin{tabular}{|c|c|c|c|c|c|c|c|c|c|}
\hline $\begin{array}{l}\text { Reference } \\
\#\end{array}$ & Reference & Comments & $\begin{array}{c}\text { Glass } \\
\text { Algorithms }\end{array}$ & $\begin{array}{c}\text { Mixing } \\
\text { and } \\
\text { Sampling } \\
\end{array}$ & Rheology & $\begin{array}{l}\text { Heat of } \\
\text { Hydration }\end{array}$ & $\begin{array}{c}\text { Glass } \\
\text { Fabrication }\end{array}$ & $\begin{array}{l}\text { Cooling } \\
\text { Curves }\end{array}$ & HGR \\
\hline & $\begin{array}{l}\text { 2013. Test Plan: } \\
\text { Enhanced Hanford } \\
\text { Waste Glass Models, } \\
\text { TR-EWG-00001, } \\
\text { Revision 0, Pacific } \\
\text { Northwest National } \\
\text { Laboratory, Richland, } \\
\text { Washington. }\end{array}$ & $\begin{array}{l}\text { glass models to } \\
\text { compositional } \\
\text { regions } \\
\text { anticipated to } \\
\text { be processed } \\
\text { through WTP }\end{array}$ & & & & & & & \\
\hline
\end{tabular}


SRNL-STI-2013-00187

Revision 0

Appendix B

Reviewed Documents Excluded from Literature Review 


\begin{tabular}{|c|c|}
\hline Reference \# & Reference \\
\hline 1 & $\begin{array}{l}\text { Arakali, A.V., D.L. Banning, P.A. Benson, and D.A. Greer. 2011. Initial Data Quality Objectives for WTP Feed } \\
\text { Acceptance Criteria, 24590-WTP-RPT-MGT-11-014, Revision 0, Bechtel, Richland, Washington }\end{array}$ \\
\hline 2 & $\begin{array}{l}\text { Arakali, A.V., and N.E. Wilkins. 2013. Integrated Sampling and Analysis Requirements Document (ISARD), 24590-WTP- } \\
\text { PL-PR-04-0001, Revision 3, Waste Treatment Plan, Richland, Washington }\end{array}$ \\
\hline 6 & $\begin{array}{l}\text { Brown, K.G., and R.L. Postles. 2006. SME Acceptability Determination for DWPF Process Control, WSRC-TR- } \\
\text { 95000364, Revision 5, Savannah River National Laboratory, Aiken, South Carolina }\end{array}$ \\
\hline 7 & $\begin{array}{l}\text { Bruce, D.A. 2012. System Description for the Cesium Nitric Acid Recovery Process - System CNP, 24590-PTF-3YD- } \\
\text { CNP-00001, Revision 2, River Protection Project, Waste Treatment Plant, Richland, Washington }\end{array}$ \\
\hline 9 & Darby, R., 2001. Chemical Engineering Fluid Mechanics, 2nd edition, Marcel Dekker. \\
\hline 12 & $\begin{array}{l}\text { Fox, K.M. and D.K. Peeler. 2007. Demonstration of Very High Aluminum Retention in Simulated HLW Glass, SRNL- } \\
\text { PSE-2007-00231, Savannah River National Laboratory, Aiken, South Carolina }\end{array}$ \\
\hline 13 & $\begin{array}{l}\text { Herman, C.C., D.E. Peeler, T.B. Edwards, M.E. Stone, and M. Smith. 2007. Process Changes to DWPF to Increase } \\
\text { Throughput and Incorporate Salt Streams, MS\&T 2007, September 2007, Detroit, Michigan }\end{array}$ \\
\hline 14 & $\begin{array}{l}\text { Herman, C.C., D.J. Adamson, D.T. Herman, D.K. Peeler, M.R. Poirier, S.H. Reboul, M.E. Stone, R.A. Peterson, J Chun, } \\
\text { J.A. Fort, J.D. Vienna, and B.E. Wells. 2013. Preliminary Assessment of the Hanford Tank Waste Feed Acceptance and } \\
\text { Product Qualification Programs, SRNL-STI-2012-00776/PNNL-22116, Revision 0, Savannah River National Laboratory, } \\
\text { Aiken, South Carolina }\end{array}$ \\
\hline 15 & $\begin{array}{l}\text { IEWO. 2011. Hanford Tank Waste Treatment and Immobilization Plant, IEWO M0SRV00028, Amendment 15, Waste } \\
\text { Qualification Program Development, Scope of Work and Technical Requirements, SCT-M0SRV0028-00-012, Revision 0, } \\
\text { River Protection Project, Waste Treatment Plant, Richland, Washington }\end{array}$ \\
\hline 16 & $\begin{array}{l}\text { IEWO. 2012. Hanford Tank Waste Treatment and Immobilization Plant, IEWO M0SRV00028, Amendment 21, Waste } \\
\text { Qualification Program Development, Scope of Work and Technical Requirements, SCT-M0SRV0028-00-012, Revision 0, } \\
\text { River Protection Project, Waste Treatment Plant, Richland, Washington }\end{array}$ \\
\hline 22 & $\begin{array}{l}\text { Kot, W.K. and I.L. Pegg. 2010. Glass Formulation Development and Testing for DWPF High-Al } \mathrm{O}_{3} \mathrm{HLW} \text { Sludges, VSL- } \\
\text { 10S1670-1, Revision 0, Vitreous State Laboratory, The Catholic University of America, Washington, DC }\end{array}$ \\
\hline 23 & $\begin{array}{l}\text { Kruger, A.A. 2013. Advances in Glass Formulations for Hanford High-Aluminum, High-Iron, and Enhanced Sulphate } \\
\text { Management in HLW Streams, to be published in the proceedings of the Waste Management Conference, February } 24- \\
28,2013 \text {, Phoenix, Arizona }\end{array}$ \\
\hline 28 & $\begin{array}{l}\text { Marra, J.C., K.M. Fox, D.K. Peeler, T.B. Edwards, A.L. Youchak, J.H. Gillam, J.D. Vienna, S.V. Stefanovsky, and A.S. } \\
\text { Aloy. 2006. Glass Formulation Development to Support Melter Testing to Demonstrate Enhanced High Level Waste } \\
\text { Throughput, WSRC-STI-2007-00236, Washington Savannah River Company, Aiken, South Carolina }\end{array}$ \\
\hline 29 & $\begin{array}{l}\text { Marra, J.C., K.M. Fox, D.K. Peeler, T.B. Edwards, A.L. Youchak, J.H. Gillam, Jr., J.D. Vienna, S.V. Stefanovsky and } \\
\text { A.S. Aloy. 2008. Glass Formulation Development in Support of Melter Testing to Demonstrate Enhanced High Level } \\
\text { Waste Throughput, Scientific Basis for Nuclear Waste Management XXXI, edited by W.E. Lee, J.W. Roberts, N.C. Hyatt, }\end{array}$ \\
\hline
\end{tabular}




\begin{tabular}{|l|l|}
\hline Reference \# & Reference \\
\hline 33 & and R.W. Grimes, Materials Research Society Symposium Proceedings 1107, Warrendale, PA \\
\hline 34 & $\begin{array}{l}\text { Nelson, J.L. and J.D. Vienna. 2009. IHLW Waste Form Compliance Plan for the Hanford Tank Waste Treatment and } \\
\text { Immobilization Plant, 24590-HLW-PL-RT-07-0001, Revision 3, Waste Treatment Plant, Richland, Washington }\end{array}$ \\
\hline 36 & $\begin{array}{l}\text { Nelson. J.L., D. Kim, L.L. Petkus, J.D. Vienna. 2011. ILAW Product Compliance Plan, 24590-WTP-PL-RT-03-001, } \\
\text { Revision. 5, Waste Treatment Plant, Richland, Washington }\end{array}$ \\
\hline 42 & $\begin{array}{l}\text { Olson, J.W. 2011. ICD 19 - Interface Control Document for Waste Feed, 24590-WTP-ICD-MG-01-019, Revision 5, } \\
\text { Waste Treatment Plant, Richland, Washington }\end{array}$ \\
\hline 43 & $\begin{array}{l}\text { Peeler, D.K., C.C. Herman, T.B. Edwards, R.J. Workman, I.A. Reamer, J.D. Vienna, J.V. Crum, D.E. Smith, and D.S. } \\
\text { Kim. 2002. Development of High Waste Loading Glasses for Advanced Melter Technologies, WSRC-TR-2002-00426, } \\
\text { Westinghouse Savannah River Company, Aiken, South Carolina }\end{array}$ \\
\hline 44 & $\begin{array}{l}\text { Peeler, D.K., E.K. Hansen, C.C. Herman, S.L. Marra, and W.R. Wilmarth. 2012. SRNL Phase 1 Assessment of the WTP } \\
\text { Waste Qualification Program, SRNL-STI-2011-00723, Revision 0, Savannah River National Laboratory, Aiken, South } \\
\text { Carolina }\end{array}$ \\
\hline $\begin{array}{l}\text { Peeler, D.K., D.J. Adamson, C.J. Bannochie, A.D. Cozzi, R.E. Eibling, M.S. Hay, E.K. Hansen, D.T. Herman, C.J. } \\
\text { Martino, C.A. Nash, F.M. Pennebaker, M.R. Poirier, S.H. Reboul, M.E. Stone, K.M. Taylor-Pashow, T.L. White, and } \\
\text { W.R. Wilmarth. 2012. SRNL Phase 1 Assessment of the WAC/DQO and Unit Operations for the WTP Waste Qualification } \\
\text { Program, SRNL-STI-2011-00724, Revision 0, Savannah River National Laboratory, Aiken, South Carolina }\end{array}$ \\
\hline $\begin{array}{l}\text { Raszewski, F.C., T.B. Edwards, and D.K. Peeler. 2008. Enhanced DOE High Level Waste Melter Throughput Studies: } \\
\text { SRNL Glass Selection Strategy, WSRC-STI-2007-00652, Washington Savannah River Company, Aiken, South Carolina }\end{array}$ \\
\hline 46 & $\begin{array}{l}\text { Slaathaug, E.J. 2011. Specification 12 - Procedure to Determine the Waste Feed Treatment Approach, River Protection } \\
\text { Project, Waste Treatment Plant, 24590-WTP-RPT-PET-11-002, Revision A }\end{array}$ \\
\hline
\end{tabular}




\section{Distribution:}

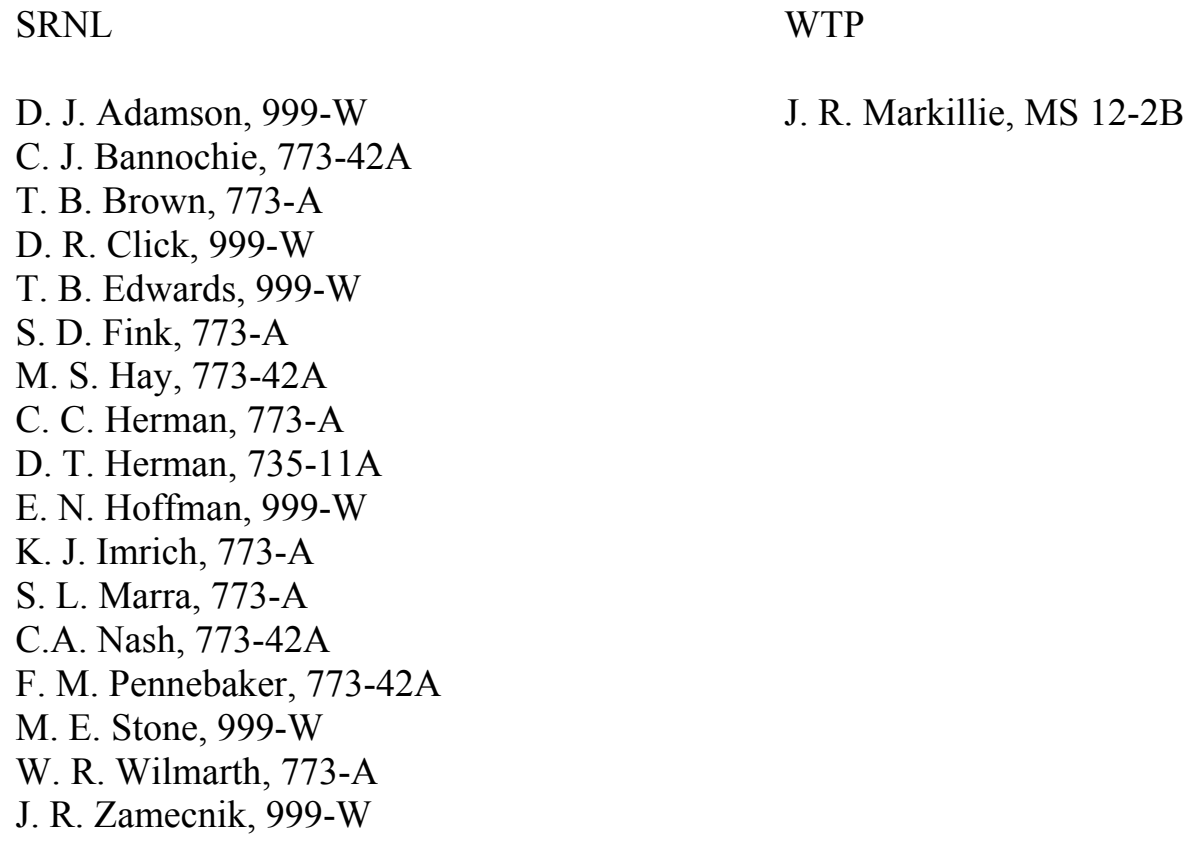

T. B. Brown, 773-A

D. R. Click, 999-W

T. B. Edwards, 999-W

S. D. Fink, 773-A

M. S. Hay, 773-42A

C. C. Herman, 773-A

D. T. Herman, 735-11A

E. N. Hoffman, 999-W

K. J. Imrich, 773-A

S. L. Marra, 773-A

C.A. Nash, 773-42A

F. M. Pennebaker, 773-42A

M. E. Stone, 999-W

W. R. Wilmarth, 773-A

J. R. Zamecnik, 999-W 